MARGARETH NODA

\title{
ACESSo Eletrônico e TendênCIAs Para A INTERMEDIAÇÃO NO MERCADO DE VALORES MOBILIÁRIOS
}

\author{
DISSERTAÇÃO DE MESTRADO
}

Orientador: Professor Titular Dr. Newton De Lucca

FACULDADE DE DIREITO DA UNIVERSIDADE DE SÃO PAULO São Paulo - 2010 


\title{
ACESSo EleTrônico E TENdÊnCIAS PARA A INTERMEDIAÇÃO NO MERCADO DE VALORES MOBILIÁRIOS
}

\author{
DISSERTAÇÃO DE MESTRADO \\ Orientador: Professor Titular Dr. Newton De Lucca
}

Trabalho apresentado à Faculdade de Direito da Universidade de São Paulo, como requisito para a obtenção do título de Mestre.

FACULDADE DE DIREITO DA UNIVERSIDADE DE SÃO PAULO

São Paulo - 2010 
Para minha sobrinha Alicia, por quem tudo vale a pena. 


\section{Agradecimentos}

Personifico em meu Orientador Professor Newton De Lucca os agradecimentos a todos os meus professores, desde a mais tenra idade. Ao Professor Newton, especialmente, agradeço pela confiança que depositou em mim e pelos ensinamentos que ultrapassaram os limites da Academia.

Ao Professor José Marcelo Martins Proença e à Professor Ilene Patrícia de Noronha, agradeço pelo incentivo e pelos comentários que me ajudaram a formatar este trabalho.

Agradeço aos meus ex-colegas do Departamento de Treinamento do Banco Bradesco S.A., por me ensinarem a aprender.

Aos meus atuais colegas da Comissão de Valores Mobiliários agradeço pelas lições diárias. Em especial, agradeço a Waldir de Jesus Nobre, a Eduardo José Busato, a Marcos Galileu Lorena Dutra, a Marcus Vinicius de Carvalho, a André Francisco Luiz de Alencar Passaro, a Isabel Sumida Hirata, a Yumi Hirai, a Fábio Bergamasco, a Hélio Rubens de Oliveira Mendes, a Márcia Tanji, a Eduardo Del Nero Berlendes e a Flávia Hana Masuko Hotta, pelo apoio, companheirismo e por confiarem mais em mim do que eu mesma.

Aos diretores da CVM, Dr. Eli Loria e Dr. Otavio Yazbek, agradeço pela generosidade de compartilharem comigo as respectivas bibliotecas e pelo estímulo que me deram.

Agradeço a Luís Antonio Gonçalves de Andrade cujas anotações foram de grande valia e, sobretudo, pelo seu dedicado auxílio durante o ano de 2009.

Finalmente, agradeço aos meus pais, Soiti e Otilia, que fizeram de mim o que sou. Aos meus irmãos, Anie Gracie e Robert, pelo que eles são; e à minha cunhada, Mariane, pela amizade mais do que fraternal. 


\section{RESUMO}

O desenvolvimento tecnológico experimentado nos últimos anos é causa de uma grande transformação no mercado de valores mobiliários. Essa transformação não se restringe aos produtos e instrumentos, cada vez mais sofisticados, mas atinge a própria estrutura de negociação. Assim, testemunhamos o abandono dos pregões viva-voz e o surgimento de sistemas de negociação eletrônica, que aumentaram a velocidade das transações e mudaram a forma de acesso ao mercado secundário de valores mobiliários. $\mathrm{O}$ presente trabalho aborda essa questão com foco na atividade de intermediação, procurando demonstrar como essa atividade é afetada pelo acesso eletrônico ao mercado, inclusive pela disciplina regulatória que tal forma de acesso impõe.

\section{Palavras chave}

mercado secundário, negociação eletrônica, acesso eletrônico, intermediação, regulação 


\section{ABSTRACT}

Technological development experienced in recent years is causing a major transformation in the securities market. This transformation is not restricted to products and financial instruments, more and more sophisticated, but reaches the very structure of trading. Thus, we witness the abandonment of open outcry system and the emergence of electronic trading systems, which increased trading speed and changed the access to secondary market securities. This paper addresses this issue with a focus on the intermediation activity, seeking to demonstrate how this activity is affected by direct electronic access, including the regulatory discipline that such form of access imposes.

\section{KEY WORDS}

Secondary market, electronic trading, direct electronic access, intermediation, regulation 


\section{SUMÁRIO}

Introdução

Capítulo 1. Mercado de Capitais e Crescimento Econômico 12

1.1. O papel da intermediação 16

Capítulo 2. Negociação de Valores Mobiliários no Mercado Secundário 23

2.1. Panorama Histórico 23

2.1.1. As Bolsas no Brasil 23

2.1.2. O Mercado de Balcão no Brasil 26

2.2. O Mercado Secundário de Valores Mobiliários no Brasil 27

2.2.1. Mercados Regulamentados de Valores Mobiliários 29

2.2.2. Entidades Administradoras de Mercados Organizados 31

2.2.3. Autorregulação dos Mercados Organizados 32

2.2.4. Telas de Acesso à Negociação em Bolsa Estrangeira 34

2.2.5.Pessoas Autorizadas a Operar 35

Capítulo 3. Negociação Eletrônica 37

3.1. Sistemas de Negociação Eletrônica 37

3.2. A Negociação Eletrônica no Brasil 40

3.2.1. Negociação Eletrônica na Bolsa 41

3.3. Efeitos da Negociação Eletrônica no Mercado 45

3.3.1. Efeito sobre a Transparência 45

3.3.2. Efeito sobre o Custo de Transação 47

3.3.3. Efeito sobre a Formação de Preços 47

3.3.4. Efeito sobre a Liquidez 49

3.3.5. Efeito sobre o Acesso ao Mercado 51 
Capítulo 4. Acesso Direto Eletrônico ao Mercado 52

4.1. Acesso Eletrônico ao Mercado por meio de Intermediário 53

4.2. Acesso Eletrônico ao Mercado não Intermediado 54

4.3. Problemas Relacionados ao Acesso Eletrônico ao Mercado 55

4.3.1. Risco de Negociação 55

4.3.2. Risco de Crédito 56

Capítulo 5. O Papel do Intermediário enquanto Provedor de Acesso Eletrônico 58

5.1. As Funções do Intermediário num Mercado Acessado Eletronicamente 60

5.1.1. Gestão de Risco de Negociação 60

5.1.1.1. Gestão do Risco de Negociação no Brasil 63

5.1.2. Gestão do Risco de Crédito 64

5.1.2.1. Gestão do Risco de Crédito no Brasil 66

5.2. Ausência do Intermediário 67

Capítulo 6. A Regulação Aplicável à Atividade de Intermediação no Contexto da Negociação Eletrônica $\quad 69$

6.1. Acesso Eletrônico e Regulação 70

6.1.1. A Regulação no Brasil 74

6.1.1.1. A Instrução CVM nº 380, de 23/12/2002 74

6.1.1.2. A Instrução CVM n ${ }^{\circ} 387$, de 28/04/2003 76

6.1.1.3. A Instrução CVM nº 301, de 16/04/1999 81

$\begin{array}{ll}\text { Conclusão } & 84\end{array}$

$\begin{array}{ll}\text { Bibliografia } & 87\end{array}$ 


\section{INTRODUÇÃo}

O mercado de valores mobiliários é indubitavelmente um dos segmentos de mercado em que as inovações se apresentam de maneira mais evidente. Dos enormes quadros-negros de pedra, em que eram registrados os negócios com ações nas Bolsas de Valores aos sistemas eletrônicos da atualidade, muita evolução ocorreu.

A forma de operação dos mercados organizados de valores mobiliários mudou e, conseqüentemente, os meios de acesso a esses mercados também mudaram. As operações são cada vez mais eletrônicas, motivadas não apenas pela necessidade da realização de negócios em escala global, mas também pela crescente demanda aos instrumentos do mercado.

Assim, os investidores requerem um novo tipo de acesso. A procura por maior controle sobre a execução das ordens, um acesso mais direto ao mercado e menor intervenção dos intermediários é crescente entre os clientes denominados sofisticados. Esse conjunto de aspirações se concretiza no que comumente se chama de "acesso eletrônico ao mercado".

Esse é o pano de fundo que motivou a realização deste trabalho. O acesso eletrônico ao mercado alterou, e imagina-se que alterará ainda mais, a atividade dos intermediários, a ponto de se discutir a sua necessidade na cadeia de negociação. Logo, o objetivo do trabalho é analisar quais as funções do intermediário no mercado de valores mobiliários, sobretudo no mercado secundário de ações, no contexto do acesso eletrônico, bem como os benefícios e problemas que a adoção dessa forma de acesso implica.

Para iniciar o tema foi feita uma breve abordagem das relações entre o mercado de capitais e o crescimento econômico, com o objetivo de discutir de que forma o mercado de capitais influencia o processo de crescimento econômico. São utilizados os conceitos de poupança e investimento e estudos empíricos que confirmam a existência de correlação positiva entre o desenvolvimento do mercado e o crescimento econômico.

A partir daí, ainda no Capítulo 1, é discutido o papel da intermediação no mercado financeiro e no mercado de capitais e as diferenças que as características desses mercados produzem na atuação dos intermediários. Também se aborda o tema da desintermediação, comumente associado ao mercado de capitais. 
O Capítulo 2 trata da negociação de valores mobiliários no mercado secundário, iniciando-se por um breve panorama histórico desse mercado no Brasil. Dá-se destaque ao mercado de bolsa, mas também se descreve sucintamente o mercado de balcão organizado.

A segunda parte desse Capítulo trata da atual organização do mercado secundário de valores mobiliários no Brasil, destacando as escolhas regulatórias feitas pela Comissão de Valores Mobiliários para a disciplina dos mercados regulamentados de valores mobiliários refletidas na Instrução CVM nº 461, de 2007, norma que reforçou o papel da autorregulação no mercado de valores mobiliários.

A negociação eletrônica é o mote do Capítulo 3. Depois da conceituação e da abordagem dos sistemas eletrônicos de negociação, faz-se uma apresentação da negociação eletrônica no mercado acionário brasileiro e se discute os efeitos gerados por essa forma de negociação.

A prática mostrou que um dos efeitos mais visíveis da implantação de sistemas de negociação eletrônica se deu sobre a forma de acesso ao mercado. O Capítulo 4 procura apresentar como o acesso se transformou e as principais formas que adquiriu, tratando do acesso intermediado e do não intermediado.

No mesmo capítulo também se colocam os desafios que as formas de acesso eletrônico impõem. Tais desafios, relacionados basicamente à gestão de riscos de negociação e de crédito, têm sido as maiores fontes de preocupação dos reguladores e dos intermediários, responsáveis primeiros pela gestão desses riscos.

O Capítulo 5 pretende aprofundar a discussão do papel do intermediário enquanto provedor de acesso eletrônico ao mercado. Para tanto, é resgatada a função da intermediação, a qual é analisada sob o prisma do acesso eletrônico, situação em que os intermediários vêem exacerbada a sua função como gestores de risco, ao mesmo tempo em que perdem o controle sobre o processo de negociação.

Finalmente, o Capítulo 6 trata da regulação aplicável à atividade de intermediação no contexto do acesso eletrônico ao mercado. Quanto à regulação brasileira, se recorre às Instruções CVM ns 301, 380 e 387, fazendo-se uma análise dos seus principais mandamentos.

Embora o objeto do capítulo seja a regulação brasileira, também se aborda o esforço no sentido da uniformização da regulação mundial representado pelos Princípios da IOCV/IOSCO. 
Espera-se que o trabalho tenha logrado êxito em apontar os benefícios e os riscos potenciais que o acesso eletrônico impõe não apenas à atividade de intermediação, mas a todo o mercado, bem como que tenha conseguido apontar caminhos adotados pela regulação e pela autorregulação. 


\section{Mercado de Capitais e Crescimento Econômico}

Embora os jornais estampem, vez por outra, artigos relacionando o Mercado de Capitais e o crescimento econômico, a tese está longe de ser unanimidade entre os teóricos do desenvolvimento.

Para entender essa relação a "Teoria do Desenvolvimento Econômico" de Schumpeter é de grande ajuda. Segundo ele, “... a função principal do mercado monetário ou de capital é o comércio de crédito com o propósito de financiar o desenvolvimento. $O$ desenvolvimento cria e alimenta esse mercado. ${ }^{1,}$

Vê-se que para Schumpeter "mercado monetário" e "mercado de capital" são expressões sinônimas ${ }^{2}$, com o que os estudiosos contemporâneos já não concordam. No entanto, é válida a afirmação de Schumpeter por que, ao mesmo tempo em que afirma ser o mercado de capital, o mesmo que popularmente se chama de mercado monetário, o autor admite a possibilidade de distinção desses dois mercados em função dos seus prazos, de forma que seria o mercado de capital, o mercado para o poder de compra de longo prazo, enquanto o mercado monetário é o mercado para empréstimos a curto prazo. Tal critério é atualmente usado para distinguir os dois mercados.

À parte as discordâncias sobre a importância do mercado de capitais para o crescimento econômico, parece consensual a posição de que, em economias de mercado, o desenvolvimento econômico está intimamente relacionado à capacidade de expansão da produção que depende da realização de investimentos, a qual, por sua vez, se viabiliza por meio da utilização de poupança.

No entanto, altas taxas de poupança não são suficientes para garantir que os investimentos sejam realizados e, consequentemente, se atinja o desejado desenvolvimento econômico. Tão importante quanto a existência de poupança, é a presença de mecanismos que propiciem o encontro dos poupadores com os tomadores de recursos, esses últimos responsáveis pela realização dos investimentos.

\footnotetext{
${ }^{1}$ In SCHUMPETER, Joseph A. "Teoria do Desenvolvimento Econômico, Uma Investigação sobre Lucros, Capital, Crédito, Juro e o Ciclo Econômico" (1934), - Tradução Maria Silvia Possas, in Os Economistas, Ed. Nova Cultural, 1997. p. 127.

${ }^{2}$ In SCHUMPETER, ob. cit. p. 124: “É o que o homem de negócios chama de mercado monetário aquele a respeito do qual todo jornal noticia diariamente sob esse título. Do nosso ponto de vista, o nome não é totalmente satisfatório: não é simplesmente o dinheiro que é negociado, e poderíamos em parte nos juntar ao protesto dos economistas contra essa concepção dele. Mas aceitamos o nome. De qualquer modo, o mercado de capital é a mesma coisa que o fenômeno que a prática descreve como mercado monetário”.
} 
Esse encontro se dá por meio do mercado financeiro e de capitais e só se torna possível se houver um sistema de intermediação eficiente. Entretanto, antes de discutir a intermediação é importante ressaltar os motivos pelos quais vem ganhado força a posição que destaca a importância do mercado de capitais para o desenvolvimento econômico e social.

Já nas primeiras lições de Macroeconomia se aprende que Poupança é igual a Renda menos Consumo. Os poupadores são, portanto, os agentes superavitários de uma economia, isto é, aqueles de gastam menos do que recebem como renda. E os investidores, quem são?

Investimento é o que permite o aumento do estoque de capital de uma economia, ou seja, investimento é um fluxo de capital novo ${ }^{3}$. Assim, investidores são aqueles que geram aumento da capacidade produtiva da economia. No entanto, nem sempre esses agentes dispõem de recursos próprios para realizarem o investimento. Se assim for, eles deverão, como agentes deficitários, buscar esses recursos junto aos poupadores.

Percebe-se que não é sem razão que se diz que o mercado de capitais é importante para o crescimento e desenvolvimento econômico. Esse mercado viabiliza a aproximação do investidor e do poupador ${ }^{4}$ e gera ganhos de produtividade e aumento da eficiência da economia como um todo.

A relevância do mercado de capitais para o desenvolvimento econômico também se mostra por meio de uma de suas principais características: trata-se de mercado que dilui riscos de novos investimentos. O mercado acionário possibilita que um indivíduo

\footnotetext{
${ }^{3}$ In HALL, Robert E. e TAYLOR, John B.. "Macroeconomia - Teoria, Desempenho e Política", Ed. Campus, 1989. p. 5, assim se define Investimento: "é a parte do PNB (Produto Nacional Bruto) usado pelas empresas para aumentarem sua capacidade produtiva e pelas famílias na aquisição de novas residências. Inclui as máquinas operatrizes, as instalações de geração de energia, as fábricas, os computadores, os prédios residenciais e as casas. Quando falam em Investimentos, os macroeconomistas estão se referindo ao valor de fábricas e equipamentos recém produzidos. Não empregam o termo em seu sentido comum de dinheiro separado como poupança. Só a compra efetiva de novos bens de capital conta como investimento.”

${ }^{4}$ In HALL e TAYLOR, ob. cit. p. 32: "Embora a poupança seja igual ao investimento numa economia fechada, não se pode dizer a mesma coisa para uma pessoa, um setor de uma economia ou uma economia aberta que tem relações com outras economias. Tomando-se emprestado, pode-se investir mais do que se poupa. Emprestando-se, pode-se poupar mais do que se investe. A capacidade de tomar emprestado ou emprestar permite que se faça investimento no lugar e na hora mais eficientes. Tomar emprestado significa acumular exigibilidades financeiras. Emprestar significa acumular ativos financeiros. Estes ativos e estas exigibilidades financeiras têm implicações para o comportamento macroeconômico.”
} 
se torne sócio de um negócio sem assumir o ônus de geri-lo e, o que é mais importante, com o comprometimento de apenas parcela de sua poupança ${ }^{5}$.

A ideia de que os mercados proporcionam serviços importantes para o crescimento econômico parece estar definitivamente consolidada. Muito se produziu sobre a contribuição do sistema financeiro para o crescimento da economia, sobretudo sobre o papel dos bancos como fornecedores de crédito ${ }^{6}$. Os estudos acerca da influência do mercado de capitais, apesar de mais recentes, apresentam conteúdo que confirma a correlação positiva entre crescimento econômico e um mercado de capitais desenvolvido.

Evidências empíricas começaram a surgir nos anos 90. Até aquele momento sobejavam os estudos teóricos. Alguns estudiosos derivaram modelos segundo os quais a liquidez do mercado de ações afeta de maneira positiva o crescimento econômico no longo prazo $^{7}$.

Concluiu-se que em mercados líquidos onde os custos de transação são mais baixos há menos desincentivo para os investimentos de longa maturação já que o investidor tem boas perspectiva de converter suas ações em dinheiro com facilidade. Em outras palavras, tão importante quanto a porta de entrada é a porta de saída.

Em um importante artigo Levine e Zervos (1998) apresentaram as conclusões de um estudo empírico que fizeram sobre a influência de variáveis de mercado tais como liquidez, volatilidade, tamanho e integração com o mercado internacional sobre as taxas de crescimento econômico, acumulação de capital, ganhos de produtividade e taxas de poupança. Foram usados dados de 47 países (Brasil incluído), no período de 1976 a 1993.

As conclusões são de que há forte correlação entre os indicadores do mercado acionário e as taxas presentes e futuras de crescimento econômico. $\mathrm{O}$ estudo não apenas abrangeu indicadores do mercado de capitais, mas também do mercado financeiro.

\footnotetext{
${ }^{5}$ In GUEDES FILHO, Ernesto Moreira et alli "O Mercado de Capitais: sua importância para o desenvolvimento econômico e os entraves com que se defronta no Brasil". Estudos para o Desenvolvimento do Mercado de Capitais. BOVESPA. 2000. p. 24. "O mercado de capitais e, especificamente, o mercado acionário permite a diluição dos riscos de novos investimentos. Constitui assim um incentivo à inovação econômica e à modernização que, por sua vez, proporcionam aumento da produtividade, maior retorno, maior crescimento, maior renda. Ao mesmo tempo, o mercado acionário promove uma democratização e socialização do capital. Permite a pulverização da participação na propriedade das empresas para os pequenos poupadores, seja diretamente, seja através de fundos mútuos ou, de maneira crescente nas economias mais modernas, através de fundos de previdência."

${ }^{6} \mathrm{O}$ próprio Schumpeter atribui ao crédito um papel importante para o desenvolvimento da economia.

${ }^{7}$ In LEVINE, Ross. “Stock Markets, Growth, and Tax Policy”. Journal of Finance, September 1991, 46 (4), pp. 1445-65.
} 
No entanto as conclusões puderam ser apresentadas separadamente e ficou demonstrado, empiricamente, que tanto a liquidez do mercado acionário, quanto o desenvolvimento do mercado financeiro apresentam forte correlação positiva não somente com taxas de crescimento atual e futuro da economia, mas também com a acumulação de capital e crescimento da produtividade.

De acordo com Levine e Zervos (1998), os resultados que obtiveram são consistentes com a visão de que uma maior facilidade de negociar ativos facilita a alocação eficiente de recursos, a formação de capital físico e apressa do crescimento econômico. $\mathrm{O}$ estudo corroborou, portanto, que há uma importante correlação positiva entre o crescimento econômico e o desenvolvimento do mercado financeiro e de capitais, e os resultados sugerem que fatores financeiros são parte integrante do processo de crescimento.

Um resultado importante da pesquisa foi a conclusão de que o tamanho do mercado acionário não tem correlação com o crescimento econômico, reforçando a visão de que mais relevante do que o tamanho do mercado são seus custos de transação e a liquidez que proporcionam aos agentes econômicos ${ }^{8}$.

Por outro lado, como alertaram Friedman e Grose (2006) em um estudo do Banco Mundial sobre o acesso ao mercado primário, os principais papéis (as ações de primeira linha ou "blue chips") são negociados em maior volume em bolsas estrangeiras do que nos mercados de origem dos seus emissores. Particularmente na América Latina, estudos do Banco Mundial apontaram que as reformas nos mercados domésticos resultaram em uma crescente proporção de emissores recorrendo ao mercado externo, o que reduziu a liquidez e enfraqueceu o mercado local.

Em vista disso, Friedman e Grose afirmam que se os grandes emissores não impulsionam o mercado doméstico, cabe aos formuladores de políticas públicas a criação de mercado para as pequenas e médias empresas, que constituem a espinha dorsal de

\footnotetext{
8 In LEVINE, Ross e ZERVOS, Sara. "Stock Markets, Banks, and Economic Growth", The American Economic Review, Vol. 88, $\mathrm{n}^{\circ}$ 3. 1998. p. 537 “... stock market liquidity and banking development both positively predict growth, capital accumulation, and productivity improvements when entered together regressions, even after controlling for economic and political factors. The results are consistent with the views that financial markets provide important services for growth, and that stock markets provide different services from banks. The paper also finds that stock market size, volatility, and international integration are not robustly linked with growth, and that none of the financial indicators is closely associated with private saving rates."
} 
qualquer economia9 ${ }^{9}$ Para tanto, concluem ser necessário um adequado arcabouço regulatório.

\subsection{O papel da intermediação}

É importante definir o papel da intermediação no mercado financeiro e no mercado de valores mobiliários, dadas as funções distintas que têm os intermediários em cada um dos mercados.

O artigo 17 da Lei $\mathrm{n}^{\circ}$ 4.595, de 1964, que trata da estruturação do sistema financeiro nacional, define as instituições financeiras:

"Art. 17. Consideram-se instituições financeiras, para os efeitos da legislação em vigor, as pessoas jurídicas públicas ou privadas, que tenham como atividade principal ou acessória a coleta, intermediação ou aplicação de recursos financeiros próprios ou de terceiros, em moeda nacional ou estrangeira, e a custódia de valor de propriedade de terceiros.

Parágrafo único. Para os efeitos desta lei e da legislação em vigor, equiparam-se às instituições financeiras as pessoas físicas que exerçam qualquer das atividades referidas neste artigo, de forma permanente ou eventual."

De acordo, com a Lei $n^{\circ} 4.595 / 64$, a intermediação é atividade das instituições financeiras. Ocorre que a definição do artigo 17 da referida Lei é demasiadamente ampla e pode levar a equívocos ${ }^{10}$, como bem salientou Eduardo Salomão Neto (2005).

\footnotetext{
${ }^{9}$ In FRIEDMAN, Felice B. e GROSE, Claire. "Promoting Access to Primary Equity Markets - A Legal and Regulatory Approach". World Bank Policy Research Working Paper 3892. April 2006. pp. 04-05: "Instead of focusing on prime issuers who, it appears, may leave home as soon as they are able, emerging markets could concentrate on improving Access to finance SMEs*, and increasing market participation by domestic retail and institutional investor. However, while many emerging markets support a stock exchange, in most cases this has not seemed to be an effective source of financing for domestic SMEs."

*SMEs: small and medium sized enterprises.

${ }^{10}$ In SALOMÃO NETO, Eduardo. Direito Bancário. Ed. Atlas. 2005. p. 14 e ss. "A definição de instituição financeira dada pelo artigo 17 da Lei ${ }^{\circ}$ 4.595/64 é desmesuradamente ampla e, se interpretada literalmente, em seu sentido puramente gramatical, poucas atividades escapariam da reserva aberta em favor das assim chamadas instituições financeiras. De fato poucas são as atividades que não envolvem a coleta, intermediação ou aplicação de recursos próprios ou de terceiros."
} 
Assim, o referido autor afirmou que a interpretação do artigo 17 deve ser feita pela exigência cumulativa de “(i) captação de recursos de terceiros em nome próprio, (ii) seguida de repasse financeiro através de operação de mútuo, (iii) com o intuito de auferir lucro derivado da maior remuneração dos recursos repassados em relação à dos recursos coletados, (iv) desde que a captação seguida de repasse se realize em caráter habitual. ${ }^{11,}$

Note-se que a atividade de uma instituição financeira consiste na intermediação, ou seja, na captação de recurso junto ao público e posterior aplicação desse recurso por meio de operações de crédito ${ }^{12}$. Não há dúvidas de que "ao cumprir o papel de intermediação financeira, as instituições financeiras deslocam recursos das unidades produtoras para consumidoras, unindo provedores e tomadores de moeda na economia. ${ }^{13 \text { ", }}$

Dessa forma, o mercado financeiro certamente desempenha papel importante no processo de crescimento econômico, visto que a aproximação de poupadores e investidores é fundamental para desencadear aquele processo.

No entanto, o papel do intermediário no mercado de capitais é substancialmente diverso do papel do intermediário no mercado financeiro. Se a intermediação nesse último significa captar recursos de terceiros em nome próprio oferecendo determinada remuneração, para emprestá-los a outrem mediante uma remuneração maior do que a utilizada na captação ${ }^{14}$, no mercado de capitais, particularmente no mercado acionário, a função do intermediário dista bastante dessa.

Vale lembrar que os intermediários atuantes no mercado de ações, quais sejam as bolsas de valores, as sociedades corretoras e as sociedades distribuidoras de

\footnotetext{
${ }^{11}$ In SALOMÃO NETO, ob. cit, p. 27.

12 In ABRÃO, Nelson, "Direito Bancário", Saraiva, 2005, p. 58, o autor afirma, citando FERRI, Giuseppe (in Manuale di Diritto Commerciale, Turim, 1971, p. 680) que para a classificação das operações bancárias deve-se considerar a importância do ato praticado, “... consoante a doutrina de Ferri: "A atividade atual dos bancos resulta de uma dúplice categoria de operações: aquelas essenciais à função que é própria dos bancos (exercício do crédito), e que consistem, de um lado, na coleta dos capitais junto aos poupadores (operações passivas) e, de outro lado, na distribuição dos capitais (operações ativas); aquelas que consistem na prestação de determinados serviços (chamados serviços bancários) a favor do público e que, não obstante a notabilíssima relevância assumida da prática, econômica e juridicamente desempenham uma função apena acessória e complementar'."
}

${ }^{13}$ In OLIVEIRA, Marcos Cavalcante de. "Moeda, Juros e Instituições Financeiras - Regime Jurídico". Forense, 2006, p. 83.

${ }^{14}$ A diferença entre a taxa de captação e a taxa de aplicação dos recursos pelas instituições financeiras é o que se denomina spread bancário. 
valores, são equiparadas a instituições financeiras, embora não desempenhem funções de instituição financeira. Tal equiparação é feita pelo artigo 18 da Lei $n^{\circ} 4.595 / 64^{15}$ e no artigo 52 da Lei $n^{\circ}$ 6.024/74, que dispõe sobre a intervenção e a liquidação extrajudicial de instituições financeiras ${ }^{16}$.

É certo que o intermediário desempenha função de relevo no mercado acionário pois esse mercado só pode ser acessado por meio de um intermediário. Em sendo assim, porque se diz que o mercado de capitais é o mercado da desintermediação?

Para responder a esta pergunta é necessário analisar as características do mercado de capitais.

Em primeiro lugar, o mercado de capitais tem como principal função o direcionamento de recursos para as entidades emissoras de valores mobiliários ${ }^{17}$, o que se dá por meio da emissão pública daqueles valores mobiliários.

${ }^{15}$ Lei $\mathrm{n}^{\circ}$ 4.595/64. Art. 18. As instituições financeiras somente poderão funcionar no País mediante prévia autorização do Banco Central da República do Brasil ou decreto do Poder Executivo, quando forem estrangeiras.

$\S 1^{\circ}$ Além dos estabelecimentos bancários oficiais ou privados, das sociedades de crédito, financiamento e investimentos, das caixas econômicas e das cooperativas de crédito ou a seção de crédito das cooperativas que a tenham, também se subordinam às disposições e disciplina desta lei no que for aplicável, as bolsas de valores, companhias de seguros e de capitalização, as sociedades que efetuam distribuição de prêmios em imóveis, mercadorias ou dinheiro, mediante sorteio de títulos de sua emissão ou por qualquer forma, e as pessoas físicas ou jurídicas que exerçam, por conta própria ou de terceiros, atividade relacionada com a compra e venda de ações e outros quaisquer títulos, realizando nos mercados financeiros e de capitais operações ou serviços de natureza dos executados pelas instituições financeiras.

${ }^{16}$ Lei $n^{\circ}$ 6.24/74. Art. 52. Aplicam-se as disposições da presente Lei as sociedades ou empresas que integram o sistema de distribuição de títulos ou valores monetários no mercado de capitais (artigo $5^{\circ}$, da Lei $\mathrm{n}^{\text {o }} 4.728$, de 14 de julho de 1965), assim como as sociedades ou empresas corretoras de câmbio.

${ }^{17}$ A definição de valores mobiliários é uma das questões mais tormentosas do Direito Comercial dada a variedade e características que apresentam. No Brasil é valor mobiliário o que consta do artigo $2^{\circ}$ da Lei $n^{\circ}$ 6.385/76, que dispôs sobre o mercado de valores mobiliários e criou a Comissão de Valores Mobiliários:

Art. $2^{\circ}$ São valores mobiliários sujeitos ao regime desta Lei:

I - as ações, debêntures e bônus de subscrição;

II - os cupons, direitos, recibos de subscrição e certificados de desdobramento relativos aos valores mobiliários referidos no inciso II;

III - os certificados de depósito de valores mobiliários;

IV - as cédulas de debêntures;

$\mathrm{V}$ - as cotas de fundos de investimento em valores mobiliários ou de clubes de investimento em quaisquer ativos;

VI - as notas comerciais;

VII - os contratos futuros, de opções e outros derivativos, cujos ativos subjacentes sejam valores mobiliários; VIII - outros contratos derivativos, independentemente dos ativos subjacentes; e

IX - quando ofertados publicamente, quaisquer outros títulos ou contratos de investimento coletivo, que gerem direito de participação, de parceria ou de remuneração, inclusive resultante de prestação de serviços, cujos rendimentos advêm do esforço do empreendedor ou de terceiros.

$\S 1^{\circ}$ Excluem-se do regime desta Lei:

I - os títulos da dívida pública federal, estadual ou municipal;

II - os títulos cambiais de responsabilidade de instituição financeira, exceto as debêntures. 
Frise-se, portanto, que o mercado de capitais tem a função econômica de permitir que as empresas façam a captação de recursos junto ao público, possibilitando a realização de investimentos (capital fixo ou estoques).

Em segundo lugar é importante ressaltar que o mercado de capitais é um mercado de risco, já que o resultado dos investidores ${ }^{18}$ dependerá do resultado da emissora dos valores mobiliários.

Se o mercado de capitais permite aos emissores acessarem diretamente os recursos dos poupadores por meio da emissão pública de valores mobiliários, então, não há que se falar em intermediação financeira no mercado de capitais. Daí se dizer que se trata de mercado desintermediado.

Sabe-se, entretanto, que as emissões públicas de valores mobiliários não prescindem de uma instituição intermediária que deve fazer a colocação dos valores mobiliários junto aos investidores ${ }^{19}$, conforme dispõe o parágrafo $2^{\circ}$, artigo $3^{\circ}$, da Instrução $\mathrm{CVM} \mathrm{n}^{\circ} 400 / 2003$ :

“\$ $2^{\circ}$ A distribuição pública de valores mobiliários só poderá ser efetuada com intermediação das instituições integrantes do sistema de distribuição de valores mobiliários ('Instituições Intermediárias'), ressalvada a hipótese de dispensa especifica deste requisito, concedida nos termos do art. $4^{\circ} . "$

A hipótese de dispensa referida trata de situações particulares disciplinadas na própria Instrução e está no âmbito da atuação discricionária da Comissão de Valores Mobiliários, observados o interesse público, a adequada informação e a proteção ao investidor ${ }^{20}$.

\footnotetext{
${ }^{18}$ Investidor aqui é usado na acepção mais corrente do termo, ou seja, "pessoa física ou jurídica que aplica as suas disponibilidades na compra de ações e títulos negociados no mercado de capitais" (verbete investidor no Dicionário Houaiss de Língua Portuguesa).

${ }^{19}$ Sobre a emissão pública de valores mobiliários deve-se verificar o art. 19 da Lei no 6.385/76.

Verificar ainda a Instrução CVM n ${ }^{\circ} 400 / 2003$, que em seu artigo $2^{\circ}$ estabelece que toda oferta pública de distribuição de valores mobiliários nos mercados primário e secundário, no território brasileiro, dirigida a pessoas naturais, jurídicas, fundo ou universalidade de direitos, residentes, domiciliados ou constituídos no Brasil, deverá ser submetida previamente a registro na Comissão de Valores Mobiliários.

${ }^{20}$ Instrução CVM nº 400/2003. Art. $4^{\circ}$ Considerando as características da oferta pública de distribuição de valores mobiliários, a CVM poderá, a seu critério e sempre observados o interesse público, a adequada informação e a proteção ao investidor, dispensar o registro ou alguns dos requisitos, inclusive publicações, prazos e procedimentos previstos nesta Instrução.
} 
A intermediação a que se refere a Instrução CVM nº 400/2003 é um negócio jurídico denominado de underwriting. O underwriting, contudo, não é uma intermediação financeira nos moldes acima descritos porque não ocorre a captação de recursos e a sua aplicação por meio de operações de crédito, como acontece nas operações do mercado financeiro. O underwriter propicia a aproximação entre o emissor e o investidor, caracterizando-se como um prestador de serviços na emissão pública de títulos, serviço pelo qual é remunerado pelo emissor.

O contrato de underwriting foi assim definido por Eizirik et alli $(2008)^{21}$ :

"O contrato de underwriting caracteriza-se como um ajuste bilateral, não solene, comutativo e de trato sucessivo. É bilateral porque gera obrigações para a companhia emissora e para o underwriter. Não solene, por inexistir qualquer formalidade específica para a sua concretização. É um contrato comutativo, na medida em que as prestações dos contratantes são de antemão conhecidas e compensam-se umas com as outras, cabendo ao underwriter receber as comissões negociadas e, em contrapartida, realizar as prestações certas e determinadas pactuadas com o ofertante. Constitui ainda um contrato de trato sucessivo, ma vez que as prestações são executadas em etapas, de modo contínuo, até o encerramento do período de distribuição dos valores mobiliários."

Ao se falar que o mercado de capitais é o mercado da desintermediação, portanto, está se falando da intermediação que ocorre no mercado financeiro que, claramente, não ocorre no mercado de capitais. Isso não significa, no entanto, que o

$\S 1^{\circ} \mathrm{Na}$ dispensa mencionada no "caput", a CVM considerará, cumulativa ou isoladamente, as seguintes condições especiais da operação pretendida:

I. a categoria do registro de companhia aberta (art. $4^{\circ}, \S 3^{\circ}$, da Lei $n^{\circ} 6.404$, de 15 de dezembro de 1976);

II. o valor unitário dos valores mobiliários ofertados ou o valor total da oferta;

III. o plano de distribuição dos valores mobiliários (art. $33, \S 3^{\circ}$ );

IV. a distribuição se realizar em mais de uma jurisdição, de forma a compatibilizar os diferentes procedimentos envolvidos, desde que assegurada, no mínimo, a igualdade de condições com os investidores locais;

V. características da oferta de permuta;

VI. o público destinatário da oferta, inclusive quanto à sua localidade geográfica ou quantidade; ou

VII. ser dirigida exclusivamente a investidores qualificados.

${ }^{21}$ In EIZIRIK, Nelson et alli. “Mercado de Capitais - Regime Jurídico”, Renovar, 2008, p. 170. 
mercado de capitais seja desprovido de intermediários, ou sequer que sua atuação seja dispensável, muito pelo contrário.

A participação dos intermediários no mercado de capitais não está restrita somente ao mercado primário, como também é de extrema relevância no mercado secundário. Ambos, como segmentos do Mercado de Capitais, têm características bem definidas.

No mercado primário se dão as emissões públicas de valores mobiliários, ou seja, em operações desse mercado os emissores captam a poupança popular que se transformará em investimento da companhia emissora, ao passo que os subscritores dos valores mobiliários passam a ter participação nos resultados da emissora, se subscritores de ações, ou passam a ser credores da companhia emissora, se subscritores de debêntures ou notas promissórias comerciais.

As operações realizadas no mercado secundário caracterizam-se pelo não ingresso de recursos para o emissor, já que não há emissão de valores mobiliários. Ocorre, portanto, uma mera negociação desses valores entre investidores sem reflexos no caixa da companhia emissora.

Poder-se-ia indagar sobre a utilidade do mercado secundário de capitais. Não há dúvidas de que se trata de segmento muito importante porque é nele que se confere liquidez aos valores mobiliários adquiridos por subscrição.

Já se viu que tão importante quanto a porta de entrada é a porta de saída. Poucos poupadores estariam dispostos a alocar seus recursos em um empreendimento se não houvesse mecanismo para a retirada dos recursos quando desejado. $\mathrm{O}$ mercado secundário é esse mecanismo. É transacionando no mercado secundário que se obtém liquidez, entendida como a propriedade do que é facilmente negociável e convertível em dinheiro, sem perda significativa de valor patrimonial.

A participação do intermediário no mercado secundário é fundamental, uma vez que as negociações do mercado secundário se dão em Bolsas de Valores ou no Mercado de Balcão, ambientes em que, no mais das vezes, é imprescindível a figura do intermediário.

Certamente, também aqui, não se trata da intermediação como ela se verifica no mercado financeiro, mas de uma intermediação que permite o acesso ao mercado de capitais, por meio da prestação de serviços de compra e venda de valores mobiliários. 
Conclui-se, portanto, que a desintermediação do mercado de capitais só existe se considerada a intermediação nos moldes do que ocorre no mercado financeiro, em que o intermediário participa da cadeia obrigacional, ou seja, é devedor daquele junto a quem captou os recursos e credor daquele a quem os emprestou ${ }^{22}$.

Assim, consideradas as características próprias da intermediação no mercado de capitais, o intermediário desempenha papel muito importante nesse mercado.

Terá ele o mesmo papel nos mercados estrangeiros, particularmente no mercado norte americano? Um breve resumo do papel dos intermediários naquele mercado é relevante pois é lá que se iniciaram as inovações que são o objeto deste trabalho e os termos que os designam apareceram nos capítulos seguintes.

Os principais intermediários do mercado acionário americano são os "brokers" e os "dealers". Legalmente, um "broker" é qualquer pessoa cuja atividade implica a negociação de valores mobiliários por conta de terceiros. Conceitua-se como "dealer" qualquer pessoa cuja atividade implica a compra e venda de valores mobiliários por conta própria e de maneira habitual.

Note-se que o "broker" não negocia, mas propicia a aproximação do comprador com o vendedor de ações, no mercado de bolsa, por exemplo. Já o "dealer" negocia para si próprio, aproveitando oportunidades e dando liquidez ao mercado.

$\mathrm{O}$ "dealer" pode atuar como "market maker", ou formador do mercado, garantindo a realização de negócios de compra e venda para o mesmo ativo a partir de sua carteira própria ${ }^{23}$.

Tem-se, portanto, que o "broker" é um prestador de serviço de intermediação, enquanto o "dealer" é contraparte do cliente nas suas transações.

Grande parte dos intermediários no mercado americano atua como "broker" e também como "dealer", daí ser muito comum a expressão "broker-dealer". Não se pode negar a existência de um possível conflito de interesses nesses casos, o que não foi ignorado pelo regulador dos Estados Unidos, a SEC - Securities and Exchange Commission, que tem regulação especial para prevenção desses conflitos.

\footnotetext{
${ }^{22}$ In EIZIRIK et alli, ob. cit., p. 4.

${ }^{23}$ Nos Estados Unidos há uma forte atuação dos "dealers". A NASDAQ, conhecida Bolsa norte-americana, por exemplo, é um "dealer market", ou seja, um mercado em que os "dealers" são responsáveis por dar liquidez aos ativos negociando-os contra as suas carteiras próprias. A Bolsa de Nova Iorque, por sua vez, é um "auction market" em que são colocadas pelos investidores ofertas de compra e de venda as quais são executadas quando se combinam em termos de preço. A Bolsa no Brasil, funciona como a de Nova Iorque.
} 


\section{Negociação de Valores Mobiliários no Mercado Secundário}

Não resta dúvida acerca da importância do mercado de capitais para o crescimento e desenvolvimento econômico. Igualmente, não pode haver dúvidas a respeito da relevância do mercado secundário de valores mobiliários.

Como a função primordial do mercado secundário é conferir liquidez aos valores mobiliários, parece razoável que a debilidade desse mercado enfraqueça também o mercado primário, uma vez que, nesse cenário, há claramente um desincentivo à aquisição de valores mobiliários que podem ser de difícil alienação no futuro.

As negociações no mercado secundário de valores mobiliários ocorrem em bolsa ou no mercado de balcão. Antes de analisarmos a atual estrutura do mercado secundário de valores mobiliários no Brasil, cabe fazer uma breve retrospectiva histórica do mercado brasileiro.

\subsection{Panorâmica Histórico}

Há alguma controvérsia acerca da origem das bolsas de valores, mas em geral se reconhece a Idade Média e suas feiras ou mercados especializados como as raízes das atuais bolsas. Durante o reinado de Felipe, o Justo, na França (1285 a 1314), teria sido criada a profissão ancestral dos atuais corretores de valores e de mercadorias.

Há quem diga que a origem da palavra "bolsa" seja a casa da família belga Van der Buerse, que se tornou um importante centro de negócios em Bruges e acabou por se tornar sinônimo de local de negociação.

É certo, entretanto, que países com tradição comercial viram surgir centros especializados em negociação e no início do século XVII as Ações da Companhia Holandesa das Índias Orientais já eram negociadas na Bolsa de Amsterdã.

\subsubsection{As Bolsas no Brasil}

No Brasil, a história do mercado de valores mobiliários teve início em 1845 , ano em que o Decreto n 417 (regulamentando a Lei $n^{\circ} 317 / 1843$ ), instituiu os “corretores oficiais de fundos públicos" 24 e ano da fundação da Bolsa de Valores do Rio de Janeiro.

${ }^{24}$ O Decreto 417 , de 14 de junho de 1845 , dispunha sobre a arrecadação do imposto sobre os corretores. Em
seu artigo $1^{\circ}$ o Decreto dispunha que "os Corretores são agentes intermediarios para comprar e vender por 
O Banco do Brasil foi a primeira companhia brasileira a ter ações listadas em bolsa, em 1851, e já no final do século XIX houve uma intensa especulação na Bolsa do Rio de Janeiro com a criação de "empresas" que se aproveitaram do aumento de liquidez causado pela política econômica de Rui Barbosa ${ }^{25}$.

Em São Paulo a Bolsa Oficial de Valores foi fundada em 1890 e alguns anos depois, em 1917, foi estabelecida a Bolsa de Mercadorias de São Paulo. No entanto, foi na década de 60, com as reformas do sistema financeiro e do mercado de capitais, que as bolsas deixaram de ser entidades oficiais corporativas, vinculadas às secretarias de finanças estaduais, para se transformarem em associações civis sem fins lucrativos.

A mesma reforma também alterou o papel dos corretores, antes nomeados pelo poder público, depois sociedades proprietárias das bolsas.

O marco para todas essas mudanças foi a Lei $\mathrm{n}^{\circ} 4.728$, de 1965, a primeira Lei do Mercado de Capitais, que disciplinou o mercado e abriu o caminho para o seu desenvolvimento. Entretanto, somente em maio de 1967, com a alteração dos Estatutos da Bolsa de São Paulo, os corretores deixaram de ser designados pelo governador do Estado sendo substituídos pelas sociedades corretoras.

Na década seguinte, em 1976, a Lei nº 6.385 criou a Comissão de Valores Mobiliários. Até então, a regulamentação e fiscalização do mercado de valores mobiliários era exercida pelo Banco Central do Brasil, por meio da Diretoria de Mercado de Capitais.

Embora houvesse muitas bolsas no Brasil ${ }^{26}$, o volume estava concentrado nas Bolsas de São Paulo e do Rio de Janeiro, sobretudo nessa última, que foi durante muitos anos a principal bolsa de valores do país.

A criação da Bolsa Mercantil e de Futuros, cujo primeiro pregão ocorreu em janeiro de 1986, teria sido parte da estratégia da Bolsa paulista para a tomada da liquidez do mercado, então concentrada no Rio de Janeiro. No entanto, somente no final da década

seus committentes, mercadorias, navios, fundos públicos, e outros effeitos e obrigações, letras de cambio, bilhetes á ordem, e quaesquer papeis commerciaes, fazer negociações por descontos, seguros, contractos em grosso, fretamentos, emprestimos sobre penhores, ou de outro qualquer modo."

25 Trata-se do fenômeno conhecido na História do Brasil como "encilhamento", provavelmente o primeiro grande escândalo financeiro do País.

${ }^{26}$ Houve nove bolsas de valores em funcionamento no Brasil. Além das Bolsas do Rio de Janeiro e São Paulo, havia a Bolsa de Valores de Minas Gerais, Espírito Santo e Brasília - BOVMESB, a Bolsa de Valores do Extremo Sul - BVES, a Bolsa de Valores do Paraná - BVPR, a Bolsa de Valores da Bahia, Sergipe e Alagoas - BOVESBA, a Bolsa de Valores de Pernambuco e Paraíba - BVPP, a Bolsa de Valores Regional (Ceará e Rio Grande do Norte) - BVRG, e a Bolsa de Valores de Santos - BVST. 
de 80, com os problemas decorrentes do que convencionou chamar de "caso Nahas" foi que a Bolsa de São Paulo cresceu em importância e passou a ocupar o lugar antes ocupado pela BVRJ.

Em 2000, a negociação com títulos e valores mobiliários foi transferida para a Bolsa de São Paulo e em 2002 a Bolsa de Mercadorias \& Futuros adquiriu os títulos patrimoniais da BVRJ.

Durante muitos anos o mercado acionário brasileiro parecia padecer de ciclotimia, alternando períodos de euforia com períodos de depressão. No final dos anos 90, no entanto, a crise do mercado era evidente, os volumes negociados decresciam ano a ano e o número de companhias listadas seguia o mesmo rumo.

A reação começou a se desenhar com o lançamento do Novo Mercado ${ }^{27}$ pela Bovespa em dezembro de 2000. Tal iniciativa, aliada a uma série de outros fatores, dentre os quais as condições macroeconômicas e o cenário externo favorável, fizeram da primeira década do milênio um período de renascimento e expansão do mercado de capitais brasileiro.

Em 2007, repetiu-se no Brasil um movimento que ocorreu em diversos países e alterou as feições das bolsas mundo afora. Trata-se do processo que a doutrina convencionou chamar de desmutualização, que ocorreu com a Bovespa e com a BM\&F.

A desmutualização nada mais é do que a conversão de uma associação, como eram as bolsas no Brasil, em uma entidade que visa ao lucro. Na realidade, ao se desmutualizarem as bolsas desatrelaram a propriedade, manifesta pelo título patrimonial, do direito de acesso aos ambientes de negociação.

Após a reforma do mercado financeiro e de capitais, as bolsas deixaram de ser entidades oficiais corporativas e se organizaram como associações, sem fins lucrativos. Para ser membro da bolsa, vale dizer, para poder intermediar negócios no seu ambiente de negociação, tornou-se necessária a aquisição de um título patrimonial da bolsa. Dessa forma, os antigos corretores organizaram-se em sociedades corretoras e adquiram títulos patrimoniais, tornando-se associados da bolsa, ou seja, proprietários da entidade.

Naturalmente, os desígnios da bolsa eram definidos pelos associados, as sociedades corretoras de valores, e a bolsa era organizada de forma a atender às

\footnotetext{
${ }^{27}$ O Novo Mercado é um segmento especial de listagem de ações de companhias que se comprometam a adotar, voluntariamente, boas práticas de governança corporativa. $\mathrm{O}$ diagnóstico de que dentre os fatores que contribuíam para o minguamento do mercado brasileiro destacava-se a falta de proteção aos acionistas minoritários, levou a Bolsa a criar um novo segmento de mercado baseado na adesão dos participantes a práticas mais rígidas do que as impostas pela legislação.
} 
necessidades dos seus associados ao menor custo possível. Nesse sentido a bolsa concedia uma série de subsídios para seus associados, o que reduzia o custo operacional das corretoras.

A crescente sofisticação do mercado e o ambiente altamente competitivo das economias globalizadas fizeram com que as bolsas brasileiras trilhassem um caminho já percorrido por muitas outras bolsas do mundo antes delas. Decidiram desmutualizar-se.

Tanto a Bovespa quanto a $\mathrm{BM} \& \mathrm{~F}$ se desmutualizaram na segunda metade do ano de 2007. Os antigos títulos patrimoniais foram convertidos em ações e a propriedade, como dito, foi desvinculada do direito de acesso. Por outras palavras, atualmente nenhuma corretora precisa ser sócia da bolsa para utilizar os serviços por ela prestados. A relação entre bolsa e sociedade corretora se dá em bases contratuais.

Organizadas sob a forma de sociedade anônima, ambas as bolsas fizeram bem sucedidas ofertas públicas iniciais de distribuição secundária e passaram a ter suas ações listadas na Bolsa de Valores de São Paulo no mesmo ano.

Se 2007 foi o ano da desmutualização, 2008 pode ser considerado o ano da reorganização societária que originou a BM\&FBOVESPA S.A. - Bolsa de Valores, Mercadorias e Futuros ${ }^{28}$. Fruto da integração das duas bolsas operantes no Brasil, a BM\&FBOVESPA constitui a maior bolsa da América Latina e ocupa lugar de destaque no cenário mundial.

\subsubsection{O Mercado de Balcão no Brasil}

Distinto do mercado de bolsa, o mercado de balcão normalmente tem suas operações realizadas por meio de contatos diretos entre os intermediários, prescindindo de um local ou mesmo de um sistema para o fechamento dos negócios.

No Brasil, se diz que o mercado de balcão é organizado quando as instituições que o administram criam um ambiente informatizado e transparente de registro

\footnotetext{
${ }^{28}$ In EIZIRIK, Nelson et alli, ob. cit., p. 237 : “As principais vantagens atribuídas ao processo que resultou na criação da BM\&FBOVESPA são: (i) a obtenção de sinergias de custos e de receitas, com potencial de racionalização nas despesas combinadas das duas bolsas; (ii) a adoção de uma estrutura integrada mais eficiente, propiciando o desenvolvimento de novos produtos e serviços, o que poderá redundar num maior volume de negociação nos mercados por elas administrados; e (iii) o fortalecimento da posição das bolsas brasileiras no processo de consolidação do mercado internacional, tornando-as um centro de referência na negociação de ações e derivativos na América Latina."
} 
ou de negociação e têm mecanismos de autorregulação. Já o mercado de balcão não organizado não conta com a supervisão de entidade autorreguladora.

O primeiro mercado de balcão organizado destinado à negociação de ações criado no Brasil foi a Sociedade Operadora de Mercado de Ativos - SOMA, adquirida pela Bolsa de Valores de São Paulo em 2002.

A BM\&FBOVESPA também é autorizada pela Comissão de Valores Mobiliários a atuar como entidade administradora do mercado de balcão organizado, embora poucas sejam as companhias listadas nesse segmento.

Em 1984 foi criada a CETIP na forma de associação destinada a prestação de serviços de custódia e liquidação financeira de títulos públicos e privados. Em 2000, a CETIP obteve autorização precária da Comissão de Valores Mobiliários para atuar como

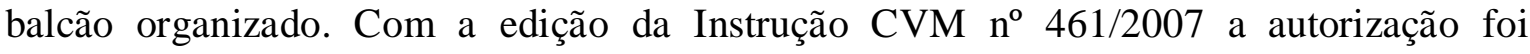
convolada em definitiva ${ }^{29}$.

Seguindo a tendência mundial, também a CETIP se desmutualizou em 2008 e abriu o capital em 2009, sob a denominação CETIP S.A. - Balcão Organizado de Ativos e Derivativos. Trata-se, sem dúvida, da principal entidade administradora do mercado de balcão organizado em operação no Brasil.

Atualmente são negociados ou registrados nos ambientes da CETIP mais de 50 tipos de ativos, de emissão pública e privada, dentre os quais as debêntures, cotas de fundos de investimento abertos e fechados e derivativos de balcão.

\subsection{O Mercado Secundário de Valores Mobiliários no Brasil}

A regulamentação do mercado secundário foi recentemente alterada pela edição da Instrução CVM no 461, de outubro de 2007, que introduziu mudanças importantes na disciplina dos mercados regulamentados de valores mobiliários e das entidades que os administram.

Seguindo a sua tradição, a Comissão de Valores Mobiliários, antes da edição da norma, submeteu uma minuta à Audiência Pública, documento no qual

\footnotetext{
${ }^{29}$ Instrução CVM no 461/2007. Art. 122. “As entidades administradoras de mercado organizado de valores mobiliários atualmente autorizadas pela CVM a funcionar, em caráter definitivo ou precário, deverão adaptar seu estatuto social e suas normas e as normas dos mercados por elas administrados às disposições desta Instrução, no prazo máximo de 270 (duzentos e setenta) dias, a contar de sua vigência.

Parágrafo único. As autorizações precárias ou condicionais hoje existentes para entidades administradoras de mercado organizado ficam convoladas em definitivas, sem prejuízo do disposto no caput."
} 
expressou os principais pontos que desejava ver debatidos, bem como explicitou a estrutura lógica da Instrução.

Antes da Instrução CVM n 461/2007, o normativo que regulava as Bolsas era a Resolução CMN n 2.690/2000, já que a Lei n 6.385/76, em seu artigo 18, dispunha que competia ao CMN e à CVM a regulação das bolsas de valores. Ocorre que a Medida Provisória $n^{\circ}$ 08/2001, convertida na Lei $n^{\circ} 10.411 / 2002$, alterou a Lei $n^{\circ} 6.386 / 76$, inclusive o artigo 18, de forma que passou a ser unicamente da CVM a competência para a edição de normas gerais relativas às bolsas, tanto de valores quanto de mercadorias e futuros, uma vez que a mesma lei ampliou a espectro de atuação da Autarquia.

Apesar de legalmente competente, a CVM ainda não havia editado normativo específico para as bolsas, de forma que continuava em vigor a Resolução CMN $n^{\text {o }} 2.690 / 2000^{30}$. O mercado de balcão, por sua vez, desde a edição da Lei $n^{\circ} 6.385 / 76$, sempre fora regulado unicamente pela CVM.

A necessidade de atualizar o arcabouço regulatório concernente às bolsas $\mathrm{e}$ ao mercado de balcão em face da existência de lacunas nos regulamentos que regiam aqueles mercados, bem como as tendências mundias que levaram à rediscussão da disciplina regulatória dos mercados, geraram o momento propício para a edição de um novo normativo que pudesse ser suficientemente flexível e abrangente para fazer frente aos desafios que o mercado impõe.

Durante a elaboração da Instrução CVM no 461/2007, não podia a CVM descuidar de dois fatores com grande influência na estrutura regulatória dos mercados: (a) o processo de desmutualização das entidades administradoras dos mercados de bolsa, e (b) o aumento da concorrência entre a negociação feita em mercados de bolsa e em outros ambientes de negociação.

Destaque-se que a Instrução CVM nº 461 deu uma nova formatação ao mercado secundário de valores mobiliários, introduzindo importantes inovações, dentre as quais merecem realce ${ }^{31}$ :

$\checkmark$ organização e estrutura mínima de governança das entidades administradoras de mercados organizados;

\footnotetext{
${ }^{30}$ A Resolução CMN n ${ }^{\circ}$ 2.690/2000 tratava apenas das bolsas de valores. Por meio da Instrução CVM n 362/2002, a CVM estendeu a aplicação dos dispositivos daquela Resolução, no que coubesse, também às bolsas de mercadorias e futuros.

${ }^{31}$ Relatório de Análise da Superintendência de Desenvolvimento de Mercado da Comissão de Valores Mobiliários - Processo CVM RJ nº 2003/11142.
} 
$\checkmark$ atividade de autorregulação das entidades administradoras;

$\checkmark$ distinção, por meio de uma abordagem classificatória, entre mercados de bolsa e de balcão organizado, juntamente com os tipos de organização possíveis para cada qual;

$\checkmark$ disciplina para autorização de instalação de telas de negociação de bolsas estrangeiras no Brasil;

$\checkmark$ substituição do fundo de garantia pelo mecanismo de ressarcimento de prejuízos, com alteração das características que o informam;

$\checkmark$ imposição de limitações à participação no capital de entidade administradora do mercado organizado de bolsa;

$\checkmark$ criação de procedimentos específicos para concessão e cancelamento de autorizações para as entidades administradoras do mercado organizado.

Uma abordagem das principais inovações de cada capítulo da Instrução possibilitará uma visão mais acurada do seu conjunto.

\subsubsection{Mercados Regulamentados de Valores Mobiliários}

São mercados regulamentados de valores mobiliários os mercados organizados e o mercado de balcão não organizado. Compõem o mercado organizado, os mercados de bolsa e balcão. Esquematicamente, assim se visualiza:

\begin{tabular}{|l|l|l|}
\hline \multirow{4}{*}{ Mercados Regulamentados } & Mercados Organizados & Bolsa \\
\cline { 2 - 3 } & & Balcão \\
\cline { 2 - 3 } & Mercado Não Organizado & Balcão \\
\hline
\end{tabular}

Os mercados organizados devem ser administrados por entidades administradoras de mercado autorizadas para tal pela CVM e não podem prescindir de uma estrutura de autorregulação.

Também é característica da Instrução a não definição conceitual dos mercados de bolsa e balcão organizado ${ }^{32}$, optando-se por uma distinção de caráter

${ }^{32}$ O Edital de Audiência Pública CVM no 06/2007 deixou claro a opção da Autarquia pela não definição conceitual dos dois mercados. Apontou como razões o aparente insucesso das regulações que assim procederam e cita como exemplo a experiência norte-americana afirmando que “... por décadas, a definição 
classificatório, com base em critérios, tais como: as regras de formação de preços, a qual deverá ser sempre pública nas bolsas; a possibilidade de acesso direto, só admitida para os mercados de balcão organizados; existência de ambientes ou sistemas para registro de operações previamente realizadas, também só possível para o balcão; e a divulgação diferida de informações relativas a operações cursadas ou registradas, igualmente só permitida ao balcão.

Ainda que as diferenças relatadas possam, em tese, se constituir em vantagem competitiva do mercado de balcão organizado, podendo aumentar a concorrência entre os dois mercados organizados, duas medidas em prol da concorrência não foram adotadas pela CVM: (a) possibilidade de dupla-listagem, e (b) a chamada "internalização sistemática de ordens".

A dupla listagem significa a possibilidade de que uma ação venha a ser listada tanto em bolsa quanto em balcão, o que foi vedado pelo artigo $57, \S 3^{\circ}$ da Instrução. Há indícios, no entanto, de que a CVM está disposta a rever essa vedação, ainda que não a curto prazo. $^{33}$

Quanto a internalização sistemática de ordens, definida pela Diretiva relativa aos Mercados e Instrumentos Financeiros da União Européia como a realização de modo organizado, frequente e sistemático, por parte de uma empresa de investimentos, da negociação por conta própria executando ordens de clientes fora de um mercado regulamentado ou de um MTF (Sistemas Multilaterais de Negociação) ${ }^{34}$, a CVM se declarou não confortável em adotá-la.

de bolsas tem sido mais um fator de insegurança do que de conforto para os mercados e, ainda hoje, a definição do que seja um ATS* é feita de forma circular e por oposição ao conceito de bolsa."

* ATS, sigla para Alternative Trading System, é definido no Regulamento dos Estados Unidos como "qualquer organização, associação, pessoa, grupo de pessoas ou sistema que: (i) constitua, mantenha ou proporcione um mercado ou instalações que busquem reunir compradores e vendedores de valores mobiliários ou que de qualquer outra forma desempenhe, com relação a esses valores mobiliários, funções ordinariamente desempenhados por uma bolsa de valores, assim consideradas de acordo com o significado do art. 3b-16 deste capítulo; e (ii) que não (a) estipule regras que disciplinem a conduta de subscritores, com exceção daqueles subscritores que negociem em tal organização, associação, pessoa, grupo de pessoas ou sistema; ou (b) discipline subscritores em outro campo que não a exclusão da autorização para negociação."

${ }^{33}$ O Edital de Audiência Pública ${ }^{\circ}$ 04/2009 dá esse indício ao explicar a adoção do princípio de "best execution", ou melhor execução, para os intermediários.

34 "Multilateral Trading Facility: A trading system that facilitates the exchange of financial instruments between multiple parties. Multilateral trading facilities allows eligible contract participants to gather and transfer a variety of securities, especially instruments that may not have an official market. These facilities are often electronic systems controlled by approved market operators or larger investment banks. Traders will usually submit orders electronically, where a matching software engine is used to pair buyers with sellers." 
Note-se que permitir a internalização equivale a elevar um intermediário ao status de mercado, o que exigiria uma disciplina regulatória muito mais complexa. A opção da CVM foi claramente por restringir a negociação de valores mobiliários aos mercados organizados, de forma que não parece haver espaço, por enquanto, para a internalização de ordens no mercado brasileiro.

\subsubsection{Entidades Administradoras de Mercados Organizados}

Os mercados organizados de valores mobiliários são estruturados e mantidos por entidades administradoras autorizadas pela CVM. A Instrução permite que a entidade administradora seja organizada sob a forma de associação ou de sociedade anônima ${ }^{35}$. Embora não haja direcionamento para uma ou outra forma, claramente a Instrução visou a antecipar e prevenir os possíveis conflitos de interesses que atingiriam as entidades desmutualizadas.

A CVM preocupou-se em estabelecer uma estrutura de governança para as entidades administradoras de mercados organizados. Devem compor essa estrutura, obrigatoriamente, (i) Conselho de Administração, no caso de mercados de bolsa, acessorado por um Comitê de Auditoria; (ii) Diretor Geral; (iii) Conselho de Autorregulação; (iv) Departamento de Autorregulação; e (v) Diretor do Departamento de Autorregulação.

Para cada um desses órgãos estão definidas as competências mínimas, bem como alguns requisitos. Um requisito importante é o de maioria de membros independentes na composição do Conselho de Administração das entidades administradoras do mercado de bolsa ${ }^{36}$. Trata-se de regra muito utilizada por outros reguladores como forma de miminizar a influência dos participantes do mercado no orgão máximo da entidade ${ }^{37}$.

\footnotetext{
${ }^{35}$ A organização sob a forma de sociedade anônima já era prevista na Resolução CMN nº 2.690/2000, no entanto tal normativo não tratava adequadamente, até pelo momento em que foi editado, dos potenciais conflitos que a adoção dessa forma de organização jurídica pode suscitar, tais como a função autorreguladora da bolsa e seus interesses comerciais

${ }^{36}$ Para as entidades administradoras do mercado de balcão organizado estabeleceu-se que, no mínimo, 25\% dos membros do Conselho de Administração sejam independentes.

${ }^{37}$ Os requisitos de independência estão no artigo 26 da Instrução CVM n ${ }^{\circ}$ 461/2007.

"Art. 26. Conselheiro independente é aquele que não mantém vínculo com:
} 
Outro dispositivo importante da Instrução está no artigo 33, o qual estabelece que "depende de autorização prévia da CVM, a aquisição, por pessoa natural ou jurídica, ou grupo de pessoas agindo em conjunto ou representando o mesmo interesse, de participação direta ou indireta igual ou superior a 15\% (quinze por cento) do patrimônio ou capital social com direito a voto de entidade administradora de mercado organizado". Tal medida visa a minimizar a possibilidade de que o controle da entidade administradora fique submetido interesses conflitantes com o interesse do mercado como um todo.

Há, ainda, um impedimento expresso a que qualquer pessoa autorizada a operar detenha participação superior a $10 \%$ no capital da entidade administradora. Trata-se de medida preventiva que objetiva evitar que uma pessoa autorizada a operar venha a controlar a entidade administradora e a utilizá-la para satisfação dos seus interesses pessoais. Visa, portanto, a proteção dos demais intermediários e ao bom funcionamento do mercado.

\subsubsection{Autorregulação dos Mercados Organizados}

Embora desde a Lei 6.385/76, em seu artigo 17, já tenha estabelecido que as bolsas e as entidades do mercado de balcão são auxiliares da CVM na fiscalização de seus membros e das operações nelas cursadas ${ }^{38}$, a ênfase à atividade de autorregulação é um dos

I - a entidade administradora, sua controladora direta ou indireta, controladas ou sociedade submetida a controle comum direto ou indireto;

II - administrador da entidade administradora, sua controladora direta ou indireta, ou controlada;

III - pessoa autorizada a operar em seu mercado; e

IV - sócio detentor de $10 \%$ ou mais do capital votante da entidade administradora.

$\S 1^{\circ}$ Conceitua-se como vínculo com as pessoas mencionadas no caput:

I - relação empregatícia ou decorrente de contrato de prestação de serviços profissionais permanentes ou participação em qualquer órgão administrativo, consultivo, fiscal ou deliberativo;

II - participação direta ou indireta, em percentual igual ou superior a $10 \%$ (dez por cento) do capital total ou do capital votante; ou

III - ser cônjuge, companheiro ou parente até o segundo grau.

$\S 2^{\circ}$ Equipara-se à relação atual, para efeito do disposto no inciso I do $\$ 1^{\circ}$ deste artigo, aquela existente no prazo de até um ano antes da posse como membro do Conselho.

$\$ 3^{\circ}$ Não se considera vínculo, para efeito do disposto no caput, a participação em órgão administrativo ou fiscal na qualidade de membro independente."

${ }^{38}$ Lei $\mathrm{n}^{\circ}$ 6.385/76. "Art. 17. As Bolsas de Valores, as Bolsas de Mercadorias e Futuros, as entidades do mercado de balcão organizado e as entidades de compensação e liquidação de operações com valores mobiliários terão autonomia administrativa, financeira e patrimonial, operando sob a supervisão da Comissão de Valores Mobiliários.

$\S 1^{\mathrm{O}}$ Às Bolsas de Valores, às Bolsas de Mercadorias e Futuros, às entidades do mercado de balcão organizado e às entidades de compensação e liquidação de operações com valores mobiliários incumbe, como órgãos auxiliares da Comissão de Valores Mobiliários, fiscalizar os respectivos membros e as operações com valores mobiliários nelas realizadas." 
principais pontos da Instrução CVM n 461/2007, pois que disciplinou a forma pela qual a autorregulação será exercida.

A Instrução estabelece que o "Departamento de Autorregulação, o Diretor do Departamento de Autorregulação e o Conselho de Autorregulação são os órgãos da entidade administradora encarregados da fiscalização e supervisão das operações cursadas nos mercados organizados de valores mobiliários que estejam sob sua responsabilidade, das pessoas autorizadas a neles operar, bem como das atividades de organização e acompanhamento de mercado desenvolvidas pela própria entidade administradora”,39

Além de uma estrutura mínima de autorregulação antes mencionada, a Instrução também estabelece que o Conselho e o Departamento de Autorregulação devem ser funcionalmente autônomos dos órgãos de administração da entidade administradora dos mercados que lhes incumba fiscalizar, bem como possuir autonomia na gestão dos recursos previstos em orçamento próprio, que deverão ser suficientes para a execução das atividades sob sua responsabilidade; e possuir amplo acesso a registros e outros documentos relacionados às atividades operacionais dos mercados que lhes incumba fiscalizar, da entidade de compensação e liquidação que preste esses serviços para os mercados, se for o caso, e das pessoas autorizadas a operar. Para tanto, a Instrução estabelece, ainda um dever de colaboração do Diretor Geral da entidade administradora ${ }^{40}$.

Quanto às competências de cada um dos órgãos que compõem a estrutura da autorregulação é importante frisar que estão todas definidas na Instrução, que, adicionalmente, estabelece requisitos de independência tanto para os membros do Conselho de Autorregulação, quanto para o Diretor de Autorregulação.

Aliás, ao lado das responsabilidades do Diretor de Autorregulação lhe foram conferidas garantias $^{41}$ para a execução do seu trabalho com isenção, uma vez que um dos

\footnotetext{
${ }^{39}$ Instrução CVM nº 461/2007, artigo 36, caput.

${ }^{40}$ Instrução CVM n 461/2007, artigo 37, caput e incisos I, II e III.

41 A Instrução determina em seu artigo 39 que o mandato do Diretor e dos Conselheiros de Autorregulação seja de três anos, passíveis de renovação. No inciso III do mesmo artigo estabelece que a perda dos mandatos só ocorre por força de renúncia, condenação judicial ou em processo sancionador instaurado pela CVM, em ambos os casos por decisão irrecorrível que leve ao impedimento ou à inabilitação, ou se assim deliberar o Conselho de Administração, com base em proposta fundamentada e detalhada acerca das circunstâncias que a justificaram, apresentada por qualquer membro do Conselho de Administração ou do Conselho de Autorregulação. Dispõe, ainda, no parágrafo único que a destituição do Diretor ou de membros do Conselho de Autorregulação, assim como as condições em que tal destituição tenha se dado, serão consideradas pela CVM ao avaliar as atividades de auto-regulação desenvolvidas pela entidade administradora, inclusive no tocante à observância do princípio de independência e autonomia.
} 
possíveis conflitos que podem surgir numa entidade administradora do mercado (sobretudo quando desmutualizada), diz respeito à contraposição de seus interesses comerciais e sua atividade como autorreguladora.

Outra forma de garantir a independência da atividade de autorregulação da entidade é a submissão à CVM do programa anual de trabalho do departamento de autorregulação. No entanto, o trabalho da Autarquia não se exaure no recebimento do programa, mas se aperfeiçoa no acompanhamento da sua execução.

\subsubsection{Telas de Acesso à Negociação em Bolsa Estrangeira}

Trata-se de uma inovação da regulamentação brasileira. A partir de outubro de 2007 passou a ser possível a instalação, no Brasil, em instituições integrantes do sistema de distribuição (nos termos do artigo 15 da Lei $\mathrm{n}^{\circ}$ 6.385/76), de telas de acesso aos sistemas de negociação de bolsas estrangeiras, o que já se concretizou com a concessão de autorização, pela CVM, a algumas bolsas estrangeiras.

A instalação de telas de acesso constitui uma real possibilidade de concorrência para os ambientes de negociação no Brasil, já que permite o acesso do investidor local aos mercados estrangeiros.

Por essa razão, foram estabelecidos critérios de autorização que levam em conta a proteção ao investidor. Essa proteção é fundamental porque tanto a bolsa estrangeira quanto os emissores de valores cujos papéis são nelas negociados não estão sob a competência regulatória da CVM.

Dentre esses critérios de proteção estão a necessidade de que o pretendente seja reconhecido como bolsa e esteja devidamente autorizado a operar como tal em seu país de origem; esteja sujeito à supervisão da autoridade reguladora de mercado de capitais de seu país de origem, com a qual a CVM mantenha convênio ou acordo de cooperação internacional ou que seja signatária do Memorando Multilateral de Entendimentos da Organização Internacional de Comissões de Valores - OICV/IOSCO; e, os requisitos exigidos para autorização e funcionamento de bolsas no país de origem do pretendente sejam, no mínimo, substancialmente equivalentes aos previstos na Instrução $\mathrm{CVM} \mathrm{n}^{\circ} 461 / 2007$.

Além disso, numa avaliação subjetiva, a CVM analisará a acessibilidade, suficiência e qualidade das informações a respeito dos ativos negociados na bolsa 
estrangeira, bem como de seus emissores e exigirá o envio de informações das transações efetuadas por investidores brasileiros no exterior utilizando-se das referidas telas.

Por fim, deve-se destacar a restrição a que apenas investidores brasileiros qualificados $^{42}$ possam negociar por meio das telas, medida adicional de proteção ao investidor local.

\subsubsection{Pessoas Autorizadas a Operar}

O artigo 11 da Instrução CVM nº 461/2007 dispõe que se considera pessoa autorizada a operar a pessoa natural ou jurídica devidamente autorizada, pela entidade administradora, a atuar nos ambientes ou sistemas de negociação ou de registro de operações do mercado organizado.

Vê-se, nos incisos do parágrafo único do mesmo artigo, que o conceito de pessoa autorizada a operar é mais amplo do que o conceito de intermediário, porque além deste, que pode atuar em nome próprio ou de terceiros, também pode ser pessoa autorizada a operar, (i) o operador especial, que atua em nome próprio ou de intermediário, e (ii) quaisquer pessoas jurídicas ou fundos de investimento, desde que atuando em nome próprio, diretamente e sem a necessidade de interferência de intermediário ${ }^{43}$.

No que respeita aos requisitos para admissão de pessoa autorizada a operar houve muita preocupação da CVM para evitar possíveis barreiras a competição. Sobretudo numa bolsa desmutualizada, não há razões para se restringir o número de pessoas autorizadas a operar.

Por outro lado, deve-se reconhecer que é essencial que a entidade administradora estabeleça critérios para a concessão de autorizações para operar. A

\footnotetext{
${ }^{42}$ Para efeito das telas de negociação em bolsas estrangeiras considera-se investidor qualificado (i) instituições financeiras; (ii) companhias seguradoras e sociedades de capitalização; (iii) entidades abertas e fechadas de previdência complementar; (iv) pessoas físicas ou jurídicas com investimentos financeiros superiores a $\mathrm{R} \$ 1.000 .000,00$ (um milhão de reais); (v) administradores de carteira e consultores de valores mobiliários autorizados pela CVM, em relação a seus recursos próprios; (vi) regimes próprios de previdência social instituídos pela União, pelos Estados, pelo Distrito Federal ou por Municípios; e (vii) fundos de investimento destinados a investidores que preencham os requisitos previstos neste parágrafo.

${ }^{43}$ Esta última hipótese é restrita ao mercado de balcão pela interpretação da norma considerando o teor do artigo 93 da Instrução CVM n 461/2007. "Art. 93. Em mercado de balcão organizado, a negociação ou o registro de operações previamente realizadas pode ocorrer sem a participação direta de intermediário integrante do sistema de distribuição de valores mobiliários, desde que neste caso, nos termos previstos no regulamento, a liquidação da operação seja assegurada contratualmente pela entidade administradora do mercado de balcão organizado, ou, alternativamente, seja realizada diretamente entre as partes da operação.”
} 
Instrução cita, em seu artigo 51, que devem ser considerados a organização do pleiteante, os recursos humanos e materiais exigíveis para o desempenho da atividade e a idoneidade e aptidão profissional das pessoas que atuem em seu nome.

Nada obstante, os requisitos de admissão como pessoa autorizada a operar devem observar os princípios de igualdade de acesso e de respeito à concorrência, mas é fundamental que as qualificações mínimas para a admissão e manutenção como pessoa autorizada a operar contemplem necessidades de patrimônio alocado à proteção de riscos de cada uma das atividades autorizadas, a segregação de atividades destinada a prevenir conflitos de interesse e a existência de departamento encarregado de verificar a observância das regras e normas de conduta aplicáveis às operações realizadas no mercado.

Ainda no que tange à concorrência, diga-se que atualmente não se restringe a capacidade de atuação em bolsa às sociedades corretoras, sendo perfeitamente possível que uma sociedade distribuidora de valores mobiliários pleiteie seu ingresso como pessoa autorizada a operar ${ }^{44}$.

Note-se que a Instrução CVM no 461/2007 apontou o caminho para o aperfeiçoamento da atividade da pessoa autorizada a operar. Esse caminho será trilhado em outro normativo da Autarquia já submetido à Audiência Pública e que deverá revogar, dentre outras, a Instrução CVM no $387 / 2003^{45}$.

\footnotetext{
${ }^{44}$ Decisão Conjunta BCB/CVM n ${ }^{\mathrm{o}}$ 17/2009. “Art. $1^{\text {o }}$ As sociedades distribuidoras de títulos e valores mobiliários ficam autorizadas a operar diretamente nos ambientes e sistemas de negociação dos mercados organizados de bolsa de valores."

${ }^{45}$ Trata-se do Edital de Audiência Pública nº 04/2009, que trouxe a minuta da Instrução que disporá sobre normas e procedimentos a serem observados nas operações realizadas com valores mobiliários em mercados regulamentados.
} 


\section{Negociação Eletrônica}

Durante muitos anos o pregão viva-voz foi a única forma de se negociar valores mobiliários em bolsa. No entanto, esse cenário mudou radicalmente com a implantação de sistemas eletrônicos de negociação, fazendo com que os pregões viva-voz começassem a perder importância e fossem totalmente abandonados na maioria das bolsas, inclusive a brasileira.

Dentre outras inovações, os sistemas eletrônicos de negociação possibilitaram que os clientes das sociedades corretoras pudessem se utilizar da Internet para colocar ordens de compra e venda de ações em bolsa. No Brasil, esse serviço começou a ser oferecido em 1999 e tem estado em franca expansão desde então ${ }^{46}$.

O home broker é apenas uma das inovações que o desenvolvimento tecnológico pôs a disposição do mercado de capitais e, hoje, apesar da sua crescente utilização, está longe de representar a modernidade no segmento.

Neste Capítulo, se fará uma abordagem dos sistemas de negociação eletrônica, dos meios de acesso eletrônico ao mercado e das influências do desenvolvimento tecnológico na forma de negociação no mercado de valores mobiliários.

\subsection{Sistemas de Negociação Eletrônica}

Historicamente, os mercados de ações eram locais onde compradores e vendedores se reuniam para negociar. Os avanços da tecnologia, com o aperfeiçoamento das comunicações reduziu a importância do local da negociação e, atualmente, compradores e vendedores se encontram de maneira virtual.

Assim, pode-se dizer que os sistemas de negociação eletrônica são os instrumentos que permitem aos compradores e vendedores trocarem informações sobre preços e ofertas de ativos financeiros e negociarem por meio de uma plataforma eletrônica. Da mesma forma se pode afirmar que eles dominam o mercado secundário de valores mobiliários, em vista da quase que completa extinção dos pregões viva-voz.

\footnotetext{
46 A BM\&FBOVESPA informou que em comparação com o ano de 2008 a média mensal de negócios via home broker cresceu 43,5\%, atingindo, em 2009, a marca de 4,12 milhões de negócios/mês. Em 2009, o volume total negociado pelo home broker foi de $\mathrm{R} \$ 468,48$ bilhões.
} 
De acordo com o BIS - Bank for International Settlements, os sistemas de negociação eletrônica são assim definidos ${ }^{47}$ :

"An Electronic Trading System is a facility that provides some or all of the following services: 'electronic order routing' (the delivery of orders from users to the execution system), 'automated trade execution' (transformation of orders into trades) and 'electronic dissemination of pre-trade' (bid/offer quotes and depth) and 'post-trade information' (transaction price and volume data)."

A negociação eletrônica ao mesmo tempo em que elimina restrições geográficas, permite uma contínua interação entre todos os participantes. É bem verdade que o telefone já havia eliminado as restrições geográficas, mas não permitia a interação simultânea com os demais participantes do mercado. O pregão viva-voz, por outro lado, permitia essa interação, mas padecia da barreira geográfica ${ }^{48}$.

No entanto, como acentua o BIS, um sistema de negociação eletrônica não é "um telefone melhorado", mas sim uma nova forma de negociar diversa dos pregões vivavoz e das transações conduzidas por telefone.

Não há dúvidas de que a negociação eletrônica permite o aumento do volume transacionado e a redução dos custos de transação. Adicionalmente, também se observa uma melhora da qualidade da informação colocada à disposição do investidor, sendo esses os motivos normalmente citados para a eletronificação dos sistemas de negociação.

Muita pesquisa se faz acerca das relações entre a forma como o mercado se estrutura e os resultados que obtém em termos de formação de preços e quantidade transacionada. A estrutura do mercado também influencia enormemente aspectos qualitativos, tais como liquidez e custos de transação e, por consequência, afeta a eficiência do mercado com reflexos no crescimento e desenvolvimento econômico.

\footnotetext{
${ }^{47}$ In "The Implications of Electronic Trading in Financial Markets", reported by a working group established by the Committee on the Global Financial System of the Central Banks of the Group of Ten Countries. BIS Bank for International Settlements. 2001, p. 3

${ }^{48}$ In ALLEN, Helen et alli. "Electronic Trading and its implication for financial systems". BIS Papers $\mathrm{n}^{\mathrm{0}} 7$ : Electronic finance: a new perspective and challenges, BIS - Bank for International Settlements, 2001, pp. 30-52.
} 
De fato, o mercado de valores mobiliários é um dos mercados em que a negociação eletrônica mais se desenvolveu. Diz-se que mercados em que os produtos são padronizados favorecem a utilização de plataformas de negociação eletrônica, mas nem sempre de forma homogênea.

Um exemplo disso é a maneira pela qual os sistemas de negociação eletrônica foram introduzidos nos Estados Unidos e na Europa. Enquanto na América o mercado acionário pode ser caracterizado por uma proliferação de sistemas de negociação eletrônica alternativos que convivem com um número comparativamente pequeno de bolsas $^{49}$, na Europa é evidente a ausência de sistemas separados, com o uso dos meios alternativos de negociação incorporado pelas bolsas ${ }^{50}$.

Tanto na Europa quanto nos Estados Unidos a migração para o uso de sistemas eletrônicos de negociação mostrou uma efetiva redução de custos.

No caso dos Estados Unidos, alterações regulatórias, promovidas em 1997, na forma de disponibilização das ordens estão diretamente relacionadas ao aparecimento dos ECNs - Electronic Communication Networks, sendo decisivas para o aumento dos sistemas de negociação eletrônica naquele país.

Os ECNs foram definidos pela SEC - Securities and Exchange Commission dos Estados Unidos na Rule 600(b)(23), segundo a qual são sistemas de negociação eletrônica que casam automaticamente ordens de compra e venda a um preço especificado. Eles são registrados junto à SEC e estão sujeitos à Regulamentação dos ATS - Alternative Trading Systems. Investidores institucionais, intermediários e formadores de mercado ${ }^{51}$ podem colocar ordens diretamente num ECN, investidores individuais, por sua vez, necessitam ser cadastrados junto a um intermediário para utilizar um ECN.

\footnotetext{
49 Não se quer dizer com isso que as bolsas de valores norte americanas não adotaram os sistemas de negociação eletrônica, pois o nível de eletronificação dos tradicionais mercados de bolsa de valores nos Estados Unidos é altíssimo.

${ }^{50}$ In ALLEN, Helen et alli, ob. cit, p. 34.

${ }^{51}$ Formador de mercado é um agente de mercado que se propõe a garantir liquidez mínima e referência de preços para ativos previamente credenciados.

Na BM\&FBOVESPA o formador de mercado pode ser uma corretora de valores, uma distribuidora de valores, um banco de investimentos ou um banco múltiplo com carteira de investimentos, que assume a obrigação de colocar no mercado, diariamente, ofertas firmes de compra e venda para uma quantidade de ativos predeterminada e conhecida por todos. Registrando essa oferta o Formador de Mercado proporciona um preço de referência para a negociação do ativo.
} 
Note-se que o ECN é uma subespécie dos ATS - Alternative Trading Systems, ou sistemas alternativos de negociação. Tais sistemas são definidos pela SEC como "ambientes de negociação não bursáteis" 52 . Em outras palavras é considerado um sistema alternativo de negociação aquele que não é regulado como uma bolsa.

$\mathrm{Na}$ Europa, por outro lado, a maior parte dos sistemas eletrônicos de negociação foi desenvolvida dentro das bolsas existentes. Os livros de ordens eletrônicos foram incorporados às tradicionais bolsas, oferecendo formas de negociação que, nos Estados Unidos, estão disponíveis apenas fora dos ambientes de bolsa ${ }^{53}$.

Allen et alli (2001) concluem que a forma como se desenvolveu o mercado de valores europeu dá reduzida oportunidade para que sistemas de negociação extra-bolsa se desenvolvam na Europa, principalmente se tais sistemas forem constituídos sob a forma de livros de ordens ${ }^{54}$. Para conquistar mercado os concorrentes deveriam ter vantagens competitivas, o que não se verificou na prática.

Argumenta-se que a desmutualização das bolsas européias deu incentivos comerciais à inovação e à busca da eficiência, o que teria motivado a adoção de sistemas eletrônicos de negociação pelas próprias bolsas.

\subsection{A Negociação Eletrônica no Brasil}

No Brasil, como visto, o mercado regulamentado de valores mobiliários prevê apenas a existência do mercado de bolsa e do mercado de balcão, inexistindo a possibilidade de sistemas alternativos de negociação.

É claro que isso não significa que não haja no Brasil sistemas eletrônicos de negociação. Como na Europa, eles tais sistemas estão na própria bolsa e no mercado de balcão.

\footnotetext{
${ }^{52}$ A Rule 300(a) do Regulamento de ATS da SEC define da seguinte forma os alternative trading system: "Any organization, association, person, group of persons, or system: (I) that constitutes, maintains, or provides a market place or facilities for bringing together purchasers and sellers of securities or for otherwise performing with respect to securities the functions commonly performed by a stock exchange within the meaning of Rule $3 b-16$ of this chapter, and (II) that does not (i) set rules governing the conduct of subscribers other than the conduct of such subscribers' trading on such organization, association, person, group of persons, or system; or (ii) discipline subscribers other than by exclusion from trading."

${ }^{53}$ In ALLEN, Helen et alli, ob. cit., p. 35.

54 Livro de ordens é um agregado de todas as ordens existentes para um determinado ativo cotado, geralmente todas as ofertas introduzidas num sistema de negociação que ainda não se concretizaram em negócios. É, portanto, composto por um conjunto de ofertas de compra e de venda com seus respectivos preços e quantidades.
} 


\subsubsection{Negociação Eletrônica na Bolsa}

O início da eletronificação da Bolsa de Valores de São Paulo se deu em 1972, quando foram instalados os painéis eletrônicos em substituição às antigas lousas onde eram registrados os preços. A partir de então, as corretoras puderam acompanhar as alterações dos preços das ações de seus escritórios, minuto a minuto, por meio de teleimpressoras. $^{55}$

Isso pode parecer pouco, quando observamos aquele cenário com os olhos de hoje, mas certamente foi uma mudança significativa para todos os envolvidos na negociação naqueles tempos.

Até 1990, quando foi implantado o primeiro sistema de negociação eletrônica da Bolsa, denominado CATS - Computer Assisted Trading System, (Sistema de Negociação Assistida por Computador) muitas inovações foram sendo incorporadas pela Bolsa, dentre as quais se destacam o desenvolvimento do sistema de custódia fungível de títulos e a implantação de uma rede de serviços on-line para as corretoras.

O CATS operou de 1990 a 1997, quando foi implantado o atual sistema de negociação eletrônica da Bolsa, o Mega Bolsa, que ampliou enormemente a capacidade de processamento de negócios.

Mesmo após a implantação dos sistemas eletrônicos de negociação, as ordens eram executadas na Bolsa tanto no pregão viva-voz quanto no sistema eletrônico, mas em setembro de 2005, ocorreu o derradeiro pregão viva-voz na Bovespa, que se tornou uma bolsa totalmente eletrônica ${ }^{56}$.

O Mega Bolsa $^{57}$ possibilita que as pessoas autorizadas a operar enviem ordens de compra ou venda remotamente, por meio de terminais de computador. De acordo com a BM\&FBOVESPA, as principais características de seu sistema de negociação eletrônica são:

\footnotetext{
${ }^{55}$ In FERREIRA, Alcides. "A Força dos Pregões”. BM\&F, 2007, p. 41.

${ }^{56}$ A Bovespa já havia abolido os pregões viva voz quando da reestruturação societária em que se uniu à $\mathrm{BM} \& \mathrm{~F}$, constituindo a BM\&FBOVESPA. No segmento de ações, portanto, o último pregão viva-voz ocorreu em 2005. Já no segmento de derivativos, oriundo da antiga BM\&F, o viva-voz resistiu um pouco mais, tendo sido abandonado em 2009.

${ }^{57}$ Trata-se de sistema desenvolvido pela Atos Euronext Market Solutions e utilizado por diversas bolsas do mundo, sendo conhecido pelo nome de Plataforma NSC.
} 
- "reproduz na tela o ambiente de negócios, exibindo os registros de ofertas e propiciando o fechamento automático de operações;

- as ofertas introduzidas pelos participantes são ordenadas com base na sequência cronológica do registro, sendo priorizado o com melhor preço;

- anuncia, em tempo real, o registro de cada negócio realizado: preço, volume, horário e corretoras participantes;

- possibilita o acesso ao histórico das operações, permitindo a conversão dessas operações em planilhas de cálculo;

- além da negociação, o sistema oferece recursos para a realização de consultas e acompanhamento do mercado de ações."

A existência de um sistema de negociação eletrônica possibilitou a oferta de uma nova forma de acesso ao mercado da Bolsa. Assim, em 1999, entrou em funcionamento o "home broker".

O "home broker" é um instrumento que permite a negociação de ações pela Internet. Para enviar ordens de compra ou de venda de ações é necessário que o investidor seja cliente de uma corretora que dispõe do sistema (em janeiro de 2010, 69 corretoras ofereciam esse serviço). Acessando sua conta no sítio de sua corretora na rede mundial de computadores, o investidor pode dar ordens limitadas ${ }^{58}$ de compra e de venda, já que o sítio de corretora está interligado ao sistema de negociação da Bolsa, o Mega Bolsa.

Após enviar sua ordem, o investidor deve acompanhar a execução de sua ordem, pois as ordens executadas são confirmadas pelo sistema.

O "home broker" é apenas uma das formas de acesso ao sistema de negociação eletrônica da Bolsa (o Mega Bolsa) por intermédio de conexões automatizadas, as quais constituem meio de o investidor enviar ordens de compra ou de venda para execução no pregão eletrônico.

Utilizando a sistemática de roteamento ${ }^{59}$, as conexões automatizadas da Bolsa permitem o envio de ordens possibilitando o atendimento de investidores agrupados

\footnotetext{
${ }^{58}$ Ordem Limitada é aquela deve ser executada a preço igual ou melhor do que o especificado pelo cliente.

${ }^{59}$ De acordo com MOURA, Alex Soares de. "Roteamento: O que é importante saber". Rede Nacional de Ensino e Pesquisa. "O roteamento é a principal forma utilizada na Internet para a entrega de pacotes de dados entre hosts (equipamentos de rede de uma forma geral, incluindo computadores, roteadores etc.). O modelo de roteamento utilizado é o do salto-por-salto (hop-by-hop), onde cada roteador que recebe um pacote de dados, abre-o, verifica o endereço de destino no cabeçalho IP, calcula o próximo salto que vai deixar o pacote um passo mais próximo de seu destino e entrega o pacote neste próximo salto. Este processo se repete e assim segue até a entrega do pacote ao seu destinatário.”
} 
em três categorias: (i) investidores individuais, que podem ser pessoas naturais, pessoas jurídicas não financeiras e clubes de investimento; (ii) investidores institucionais, dentre os quais estão os fundos mútuos de investimento, os fundos de previdência privada e as seguradoras; e (iii) investidores instituições financeiras, que são as carteiras próprias das instituições financeiras.

Os intermediários autorizados a operar na Bolsa são os responsáveis por construir ou contratar os serviços e sistemas de roteamento para o uso de seus clientes, com a função de tratar as ordens, aprová-las e enviá-las à Bolsa por meio das Conexões Automatizadas.

De forma esquemática, se pode representar da seguinte forma:

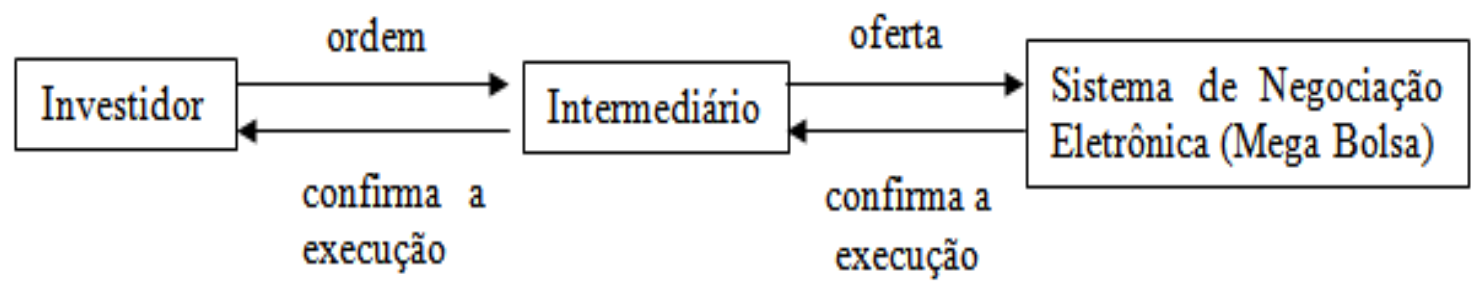

O investidor envia a ordem por meio de um terminal de computador ao intermediário. Este trata a ordem, verificando limites de negociação do investidor, por exemplo, e a encaminha para o sistema de negociação eletrônica da Bolsa. Se a ordem for executada, o sistema confirma a execução para o intermediário que transmite a informação para o investidor. Como todo o processo é eletrônico, tudo isso ocorre em apenas alguns segundos.

Como visto, três categorias de clientes podem se utilizar do roteamento de ordens por meio das conexões automatizadas, para cada um desses grupos de clientes a Bolsa estabeleceu condições de acesso:

$\checkmark$ Conexão Varejo: é destinada à recepção de ordens encaminhadas pelos clientes investidores individuais. Há duas "portas" de acesso à essa conexão: (i) o "home broker", que é acessado exclusivamente por clientes finais, que sejam investidores individuais, com o uso de senhas próprias cadastradas junto ao intermediário; (ii) a 
porta acessada exclusivamente por repassadores de ordens ${ }^{60}$, operando para clientes investidores individuais.

$\checkmark$ Conexão Gestor: é destinada à recepção de ordens encaminhadas por gestores de ordens $^{61}$ por meio de porta acessada exclusivamente pelos referidos gestores operando para seus clientes de qualquer categoria.

Conexão Institucional: é destinada à recepção do roteamento de ordens de clientes investidores institucionais e de clientes investidores instituições financeiras.

A concessão de autorização, por parte da Bolsa, para que um intermediário autorizado a operar possa oferecer o serviço de roteamento de ordens a seus clientes é precedida da assinatura de um contrato em que o intermediário assume a responsabilidade pelo atendimento dos requisitos técnicos e regulamentares.

Dentre os requisitos técnicos estão os relacionados à segurança do sistema e à efetividade dos controles que a assegurem, evitando tanto os acessos indevidos, quanto as fraudes por manipulação de dados, a espionagem, a obtenção de dados e a revelação ilegal de informações.

$\mathrm{Na}$ categoria dos requisitos regulamentares está a aceitação das normas e procedimentos emanados pela Bolsa, inclusive no que tange à aplicação de penalidades pelo descumprimento das obrigações acordadas.

Vale lembrar que ao permitir o roteamento de ordens pelos seus clientes, os intermediários assumem a responsabilidade pelas ofertas introduzidas no sistema de negociação eletrônica da Bolsa, pelas operações realizadas naquele sistema e pela liquidação física e financeira das operações efetuadas.

É perceptível a forma como a negociação eletrônica alterou os procedimentos da Bolsa. Hoje não há dúvidas de que o componente mais valioso de uma bolsa é o seu sistema de negociação, pois é ele que possibilita a interação dos intermediários e dos investidores com a própria bolsa.

\footnotetext{
${ }^{60}$ Repassadores de ordens são os empregados de instituição intermediária; os administradores de carteira que sejam pessoas físicas, vinculados à instituição intermediária; e os agentes autônomos de investimento vinculados a instituições intermediárias.

${ }^{61}$ Gestores de ordens são os administradores de carteira que sejam pessoas físicas ou jurídicas, devidamente credenciados junto à CVM para o exercício dessa atividade; as instituições intermediárias; e os administradores de carteira de clientes sediados no exterior, devidamente registrados junto a órgão regulador do país de origem.
} 
Também indiscutível é o fato de que a forma de negociação eletrônica causa efeitos no mercado. Tais efeitos serão tratados a seguir.

\subsection{Efeitos da negociação eletrônica no mercado}

Se por um lado a negociação eletrônica estimula o aumento do número de ambientes de negociação, como visto nos Estados Unidos, por outro lado ela também facilita a consolidação do mercado, explorando os ganhos de eficiência, como ocorreu no Brasil $^{62}$.

Qualquer que seja o resultado, fragmentação ou consolidação do mercado, os efeitos da negociação eletrônica são normalmente associados à transparência, aos custos de negociação, à formação de preços, à liquidez e ao acesso ao mercado.

\subsubsection{Efeitos sobre a Transparência}

Considerada como a habilidade dos participantes do mercado em obter informações acerca do processo de negociação ${ }^{63}$, pode-se dizer que o aumento da transparência antes e após a negociação é um dos benefícios mais claros da negociação eletrônica.

De acordo com Madhavan (2000), as informações relativas à transparência na negociação podem ser o conhecimento de preço, ofertas, volume, fluxo de ordens, a identidade dos intermediários, dentre outras. É importante separar as informações antes da negociação (o chamado pré trading) e após a negociação (pós trading) ${ }^{64}$.

A transparência na pré-negociação está relacionada ao acesso ao livro de ordens. A pós-negociação diz respeito a divulgação de informação sobre os negócios fechados, com preço, quantidade, horário de execução e intermediários envolvidos.

\footnotetext{
${ }^{62}$ Embora o mercado secundário brasileiro tenha passado por um processo de consolidação, não se pode atribuí-lo apenas à introdução da negociação eletrônica pela Bolsa de Valores de São Paulo. Por outro lado, não se pode minimizar a importância que o sistema da bolsa tem no processo de consolidação, pois o que se observou no Brasil guarda relação com o que a doutrina descreve como processo de consolidação.

63 Esta é apenas uma das formas de se conceituar a transparência de mercado, não há uma definição consensual.

${ }^{64}$ In MADHAVAN, Ananth. "Market Microstructure: a Survey”, 2000, Disponível em http://ssrn.com/abstract=218180 or doi:10.2139/ssrn.218180, último acesso em 09/01/2009
} 
Apesar de criarem condições para um alto nível de transparência em todo o processo de negociação, já que abrem a possibilidade de disseminação em tempo real a todo o mercado de informações pré e pós-negociação, os sistemas eletrônicos de negociação também podem operar com grande opacidade.

Tal opacidade é, normalmente associada com a exigência dos participantes de negociarem anonimamente. Dessa forma, alguns dos sistemas eletrônicos de negociação foram desenvolvidos com a finalidade de eliminar a prestação de informações prénegociação que podem fornecer "pistas" valiosas sobre a estratégia do negociador.

Os "Dark Pools" ${ }^{65}$ são típicos exemplos de ambiente de negociação de altíssima opacidade. Trata-se, essencialmente, de sistemas de negociação privada em que os participantes podem negociar sem divulgar suas ofertas para o público ${ }^{66}$. As maiores "Dark Pools" são patrocinadas por grandes intermediários para executar tanto as ordens de seus clientes quanto para fazer os negócios de suas carteiras próprias.

Como o próprio nome que receberam nos Estados Unidos indica, o princípio de um "Dark Pool" é a não revelação de informações concernentes aos negócios realizados, o que facilitaria a negociação de grandes volumes sem que se afetem os preços. Percebe-se, portanto, que um "Dark Poll" é um sistema de negociação alternativo (ATS), mas que difere dos ECNs, pois nesses últimos os negócios são publicamente divulgados, o que não ocorre num "Dark Pool".

Embora potencialmente, como visto, os sistemas de negociação eletrônica aumentem a transparência das transações, e o fazem na maior parte das vezes, também é possível que se prestem justamente ao aumento da opacidade das transações, como ocorre com os "Dark Pools".

Deve-se reconhecer que os interesses dos diversos agentes do mercado não são congruentes, e que existe uma racionalidade a fundamentar a existência de ambientes de negociação não transparentes. Cabe, no entanto, ao regulador sopesar as virtudes e defeitos de cada sistema e definir qual o bem jurídico mais importante, que deve ser tutelado.

\footnotetext{
${ }^{65}$ Sistemas idênticos podem ser referidos com outras denominações, tais quais, "upstairs market" , "dark liquidity" ou "dark pool of liquidity".

${ }^{66}$ Os "Dark Pools" são "crossing networks" que executam ordens de compra e de venda eletronicamente, sem que essas ordens passem por sistemas de bolsa ou outros sistemas que divulguem informações publicamente.
} 


\subsubsection{Efeitos sobre os custos de negociação}

São custos de negociação os incorridos para adquirir ou vender um valor mobiliário, decorrentes da cobrança de comissões e tributos, bem como os incorridos para a obtenção de informações. Dito de outra forma, são custos intrínsecos às negociações de qualquer espécie. Podem ser custos explícitos, tais como a taxas de corretagem, ou implícitos, tais como a diferença entre as ofertas de compra e venda ${ }^{67}$ (bid-ask spreads).

Intuitivamente, se conclui que custos de negociação mais baixos reduzem o custo de capital e refletem na qualidade do mercado de valores mobiliários.

Ao reduzirem o custo operacional dos ambientes de negociação, os sistemas eletrônicos, proporcionam custos menores para os investidores ${ }^{68}$. Não são desprezíveis, igualmente, as economias decorrentes de redução de erros. No entanto, mais importante é o ganho decorrente da automatização de processos relativos à execução e liquidação das operações e os controles de risco a elas inerentes.

Quanto aos custos implícitos, estudos sugerem que eles caíram ao longo dos últimos anos, o que se atribui, pelo menos em parte, à eletronificação dos sistemas. A maior transparência do mercado reduz os prêmios de risco e além disso, aumenta a competição pela maior facilidade de comparação de preços, razão pela qual, todas as demais condições semelhantes, a diferença de preços das ofertas de compra e de venda tende a ser menor na negociação eletrônica do que nos ambientes de negociação tradicionais.

\subsubsection{Efeitos sobre a formação de preços}

A formação de preços na negociação eletrônica está muito associada aos "algorithmic trading" 69 , que consistem no uso de programas de computador para colocar ordens de compra e de venda com o uso de algoritmos matemáticos que determinam o

\footnotetext{
${ }^{67}$ Trata-se da diferença entre o maior preço que um comprador está disposto a pagar e o menor preço pelo qual o vendedor está disposto a vender um ativo.

${ }^{68}$ Apenas a título de exemplo, para uma mesma operação há diferenças de custo para o investidor, se ela for feita pelo "home broker" ou diretamente na mesa de operações da corretora. Não é sem razão que as corretoras estimulam os pequenos investidores a utilizarem os canais eletrônicos de atendimento.
}

69 “Algorithmic trading" também são referidos como "automated trading”, "algo trading”, "black-box trading" ou "robo trading". 
momento da colocação da ordem, o preço, a quantidade a ser negociada sem a interferência humana. Um "algorithmic trader" equivale ao piloto automático de uma aeronave.

Em interessante estudo empírico sobre os efeitos da mudança da negociação viva-voz para a negociação eletrônica, Jain (2006) concluiu que apenas a divulgação da mudança de padrão tecnológico (pregão tradicional para negociação eletrônica) já foi suficiente para causar uma resposta positiva dos preços dos ativos negociados. ${ }^{70}$

Inegavelmente, os preços incorporam mais rapidamente as informações disponíveis num sistema de negociação eletrônica, pelo menos no curto prazo.

No que tange à volatilidade, entendida como uma medida estatística da dispersão dos retornos de um determinado ativo em um dado período de tempo ${ }^{71}$, estudos não comprovaram que os sistemas de negociação eletrônica tenham algum efeito significativo sobre essa variável. No entanto, muitos participantes de mercado sugerem que a volatilidade é mais perceptível quando há um aumento do nível de transparência dos negócios realizados.

Uma questão interessante no que diz respeito à influência dos sistemas de negociação na formação de preços está relacionada a alguns ambientes de negociação de alta opacidade.

Nesses casos, como visto, pouca informação é divulgada, o que pode suscitar dúvidas quanto à equidade das transações. Tome-se como exemplo os "Dark Pools" e sistemas que fazem internalização de ordens. Tanto num como noutro a falta de transparência gera incertezas sobre os preços praticados.

Em ambos os casos, contudo, há que se reconhecer que a forma por meio da qual se dá a negociação naqueles ambientes pode influenciar positivamente os preços formados, seja pela redução de custos que representam, seja porque se constituem em importante forma de evitar vazamento de informações sobre a negociação (sobretudo no caso dos “Dark Pools").

\footnotetext{
${ }^{70}$ In JAIN, Pankaj K. "Financial Market Design and Equity Premium: Electronic versus Floor Trading”, Working Paper, 2006.

${ }^{71}$ A volatilidade é uma medida do risco de mudança do preço de um ativo. Um ativo de alta volatilidade pode ter seu preço alterado dramaticamente em ambas as direções em um curto período de tempo. Um ativo de baixa volatilidade, por outro lado, tende a apresentar mudanças de preço mais suaves.
} 


\subsubsection{Efeitos sobre a liquidez}

Os sistemas de negociação eletrônica podem aumentar a liquidez no mercado secundário porque reduzem os custos de negociação, aumentam a qualidade da informação prestada, reduzindo, portanto a assimetria informacional e contribuindo para a redução de práticas abusivas ${ }^{72}$.

Além disso, ao propiciarem acesso remoto aos investidores, os sistemas eletrônicos também facilitam a negociação e aumentam a liquidez.

No mercado se diz que liquidez gera liquidez, provavelmente por isso alguns ambientes de negociação retomaram a realização de leilões periódicos para os ativos menos líquidos. Esses leilões têm o objetivo de concentrar a liquidez em determinados momentos, liquidez esta que estaria dispersa em um período de tempo mais longo ${ }^{73}$.

As mais recentes discussões sobre a liquidez do mercado secundário envolvem uma nova forma de negociar, o chamado "high frequency trading" (HTF), ou negociação de alta frequência, numa tradução livre que não é utilizada no Brasil.

$\mathrm{O}$ "high frequency trading” só é possível em razão dos sistemas eletrônicos de negociação, sendo por muitos considerado como uma decorrência natural dos sistemas eletrônicos.

Não há uma definição exata do que seja o "high frequency trading”, mas em discurso proferido no Senado dos Estados Unidos em 28/10/2009, James Brigagliano, da Divisão de Negociação e Mercados da SEC, reconhecendo a ausência de um conceito claro, descreveu o "high frequency trading" como uma estratégia que se utiliza de um grande número de ordens de compra ou venda, bem como de um grande número de cancelamentos dessas ordens (normalmente em uma fração de segundos), fazendo com que o investidor entre e saia de posições muitas vezes durante um mesmo dia.

É claro que um operador, por mais veloz que fosse, não conseguiria a façanha descrita acima. Isso só é possível pelo uso de computadores e programas que, em

\footnotetext{
${ }^{72}$ In JAIN, Pankaj K., ob. cit. p. 21.

${ }^{73}$ In ALLEN, Helen et alli, ob. cit., p. 46, descreve-se o exemplo da Bolsa de Varsóvia que retomou atividades em 1991 realizando um leilão semanal, passando a realizar leilões diários e, posteriormente, para algumas ações, havia sessões de negociação permanentes. Isso só foi possível porque o volume negociado cresceu suficientemente para proporcionar boa liquidez.
} 
velocidades inimagináveis ${ }^{74}$, enviam ordens (e também as cancelam, se for o caso) para os sistemas de negociação eletrônica existentes.

Para esses investidores é fundamental que a "latência", entendida como o tempo entre a emissão da ordem e a sua execução, seja reduzida ao mínimo.

A SEC reconhece que o "high frequency trading" desempenha um importante papel nos mercados atuais, sendo responsável por uma grande parte da liquidez disponível tanto nas bolsas, quanto em outros ambientes de negociação. No entanto, o regulador norte-americano tem demonstrado uma grande preocupação com potenciais danos aos interesses dos investidores de longo-prazo.

Isso ocorreria em razão da capacidade dos "high frequency traders", normalmente instituições financeiras, de acessar os mercados mais rapidamente do que os demais participantes por meio do uso de algoritmos de negociação e de "co-location"75. Essa capacidade permite ao "high frequency trader" colocar ou cancelar ordens mais rapidamente do que os investidores de longo-prazo, o que pode resultar em condições de negociação menos favoráveis para esses investidores.

No entanto, também se reconhece que o "high frequency trading" teve papel importante na crise de 2008/2009 gerando liquidez para o mercado. A estratégia também é associada à redução dos spreads, o que é visto como positivo.

A Bolsa de Nova Iorque admite a importância do "high frequency trading" em seu ambiente. Na verdade, acredita-se que mais de $60 \%$ do volume transacionado no mercado norte americano seja proveniente desse tipo de negociação ${ }^{76}$.

Como se percebe não está claro se os "high frequency traders" são bandidos ou mocinhos nessa estória. A SEC, por exemplo, já disse que quer ouvir todos os

\footnotetext{
${ }^{74}$ Nesse mercado o tempo não se mede em minutos, nem em segundos. Para se ter uma ideia da velocidade com que são feitas as transações, o tempo é medido em milisegundos (um milisegundo é um milésimo de um segundo), ou mesmo em microsegundos (um microsegundo é um milionésimo de um segundo). Recentemente um gerente de mercado da IBM afirmou que a velocidade da luz é a meta para alguns dos seus clientes.

75 "Co-location" é um contrato que permite ao investidor hospedar seu servidor no centro de processamento de dados do ambiente de negociação para reduzir o tempo de transmissão de suas ordens.

${ }^{76}$ A NYSE - New York Stock Exchange deve inaugurar, no segundo semestre de 2010, o seu novo centro de processamento de dados. Ele ficará localizado a cerca de $55 \mathrm{~km}$ de Wall Street, mede aproximadamente 37.000 metros quadrados e custou US\$250 milhões. Com esse novo centro de processamento a NYSE terá capacidade de processar 15 milhões de mensagem por segundo, o que significa algo em torno de 75 vezes o processamento exigido para o volume atual de operações. De acordo com a NYSE, 95\% do espaço destinado ao co-location já está locado, razão pela qual está se considerando ampliar o espaço destinado a isso.
} 
participantes do mercado para definir uma possível nova regulamentação para o mercado dos Estados Unidos no que tange à atuação desses personagens.

\subsubsection{Efeitos sobre o acesso ao mercado}

Os sistemas de negociação eletrônica afetam o acesso ao mercado de muitas formas. As limitações físicas ao número de participantes deixam de ser um fator preponderante, as limitações geográficas são eliminadas, abre-se caminho para a entrada de novos participantes no mercado e os emissores podem atingir um grupo maior de potenciais investidores ${ }^{77}$.

Todas essas mudanças afetam a forma como o mercado se estrutura, inclusive quanto ao papel a ser desempenhado por cada participante da cadeia de negociação.

Não há dúvidas de que nos atuais mercados há espaço para a especialização e atuação em nichos específicos tanto para os ambientes de negociação quanto para os intermediários que neles atuam, o que já se verifica em grande medida.

Quanto aos intermediários, pode-se, inclusive discutir se, no cenário da negociação eletrônica, ainda há um papel a ser por eles desempenhado, ou se sua presença pode ser eliminada. Tal discussão passa pela função da intermediação no mercado de valores mobiliários que, como visto, difere da função desempenhada pelo intermediário do sistema financeiro.

No próximo capítulo o papel do intermediário num mercado em que o acesso é cada vez mais eletrônico será discutido.

77 In ALLEN, Helen et alli, ob. cit., p. 39. Nesse cenário, questões regulatórias ganham ainda mais relevância. Ainda que o desenvolvimento da tecnologia não obste o acesso ao mercado, podem os reguladores impor limites a esse acesso. 


\section{Acesso Direto Eletrônico ao Mercado}

Até aqui tratou-se do mercado secundário de valores mobiliários, com ênfase no mercado acionário, e de como os sistemas eletrônicos mudaram a forma de negociação nesse mercado.

Embora as mudanças se manifestem de várias maneiras, o acesso ao mercado talvez seja a face mais evidente da introdução das inovações, uma vez que se trata da forma por meio da qual o investidor consegue se utilizar efetivamente do mercado.

Não se pode negar que nos últimos anos houve uma demanda crescente por acesso aos mercados globais, o que também contribuiu para que os meios de acesso ao mercado incorporassem muitas inovações.

Assim, chegou-se ao acesso direto eletrônico ao mercado ("direct electronic access", em inglês). Não há uma definição precisa para a expressão ${ }^{78}$, que sequer é uniformemente utilizada em todo o mundo. Optou-se por utilizar a expressão acesso direto eletrônico ao mercado, ou simplesmente acesso eletrônico, por ter sido ela escolhida pela OICV/IOSCO - Organização Internacional das Comissões de Valores ${ }^{79}$, para designar a forma de acesso de que se trata.

Apesar de não haver absoluto consenso a respeito da expressão acesso eletrônico ao mercado, normalmente há concordância de que o acesso eletrônico se subdivide em duas categorias: o acesso intermediado e o não intermediado.

Adotando a posição da OICV/IOSCO, o acesso intermediado pode se dar de duas formas distintas: (i) os investidores, clientes de um intermediário, têm acesso direto ao mercado por meio de sistema registrado junto a esse intermediário ou pela infraestrutura proporcionada pelo intermediário, como, por exemplo, no roteamento de ordens; (ii) os investidores, clientes de um intermediário, têm acesso direto ao mercado sem passar pelo sistema ou estrutura do intermediário, como, por exemplo, no acesso patrocinado.

\footnotetext{
${ }^{78}$ Há muitas referências à expressão Acesso Direto ao Mercado (“Direct Market Access" - DMA) que, muitas vezes, é utilizada como sinônimo de "acesso eletrônico ao mercado".

${ }^{79}$ Mais conhecida como IOSCO - International Organization of Securities Commissions, a OICV é uma organização que congrega mais de cem reguladores do mercado de valores mobiliários do mundo todo, sendo reconhecida como o organismo de cooperação internacional mais representativo desse mercado. Sua sede fica em Madri, na Espanha.
} 
Em ambos os casos, as ordens encaminhadas pelos investidores são recebidas pelo ambiente de negociação como provenientes do intermediário, por isso se denomina intermediado esse acesso.

No acesso não intermediado, por outro lado, o acesso ao ambientes de negociação ${ }^{80}$ se dá diretamente a investidores que não os intermediários (que naturalmente têm acesso ao mercado). Tais investidores ficam, portanto, habilitados a acessar o mercado sem nenhuma interferência de um intermediário.

Em resumo, a expressão acesso eletrônico ao mercado pode se referir a um sistema automático de roteamento de ordens, a um acesso patrocinado ou ao acesso não intermediado, também conhecido como acesso direto puro.

A implementação do acesso eletrônico trouxe uma série de vantagens para os participantes do mercado: os investidores conseguem maior controle sobre suas decisões de investimento e reduziu-se o tempo de execução, a chamada latência. Além disso aumentou a transparência da negociação e a capacidade das entidades administradoras de mercado e dos próprios intermediários de desenvolver e aplicar ferramentas automáticas de gestão de $\operatorname{riscos}^{81}$.

Por outro lado há uma série de questões regulatórias, concernentes, sobretudo, as possibilidades do "high frequency trading", do "co-location" e mesmo algumas questões relacionadas à gestão de riscos que não foram resolvidas e merecem maior discussão.

\subsection{Acesso Eletrônico ao Mercado por meio de Intermediário}

Em ambas as formas de acesso eletrônico ao mercado por meio de intermediário uma característica é marcante: não há intervenção humana no período compreendido entre a inserção da ordem pelo investidor e a sua execução ${ }^{82}$.

\footnotetext{
${ }^{80}$ Destaque-se que, no Brasil, só podem ser ambientes de negociação as entidades administradoras do mercado de bolsa ou de balcão. No mercado dos Estados Unidos há as bolsas e os sistemas alternativos de negociação.

81 “Policies on Direct Electronic Access - Consultation Report"- OICV-IOSCO Technical Committee, 2009.

${ }^{82}$ Como visto anteriormente, muitas vezes sequer há intervenção humana na própria colocação da ordem. É o que acontece quando os "algorithmic traders" e os "high frequency traders" operam. A inserção de ordens no sistema é feita pelos programas de computador, sem intervenção humana, portanto.
} 
Quando o acesso é garantido por meio da infraestrutura do intermediário, ou seja, quando as ordens passam pelo intermediário antes de atingirem o sistema de negociação para o qual foram dirigidas, o intermediário mantém a capacidade de monitorar as ordens transmitidas e, se for o caso, impedir a continuidade do fluxo.

É o que acontece, por exemplo, com o sistema de roteamento utilizado pela Bolsa no Brasil no mercado de ações ${ }^{83}$. O intermediário tem espaço para interferir antes que a ordem chegue ao Mega Bolsa. Tal intervenção ocorre, por exemplo, por meio da conferência da existência de disponibilidade de limites para a negociação pretendida pelo cliente. Evidentemente, a interferência do intermediário se faz por meio de sistemas eletrônicos, de outra forma não se garantiria a rapidez da operação.

Quando o acesso, ainda que intermediado, ocorre de forma patrocinada, por outro lado, o intermediário não conta com a mesma possibilidade de interferência no processo. Muitas vezes o intermediário é cientificado de uma transação depois de ela já ter ocorrido, o que, consequentemente elimina sua chance de intervenção antes da negociação.

\subsection{Acesso Eletrônico ao Mercado não Intermediado}

O acesso eletrônico não intermediado permite que os investidores coloquem ofertas de compra e venda de valores mobiliários diretamente no sistema de negociação da entidade administradora do mercado. Tal tipo de acesso dispensa a necessidade de que os investidores sejam clientes de um intermediário já que o acesso é concedido diretamente pela entidade administradora do mercado.

No Brasil, a norma da CVM que regula os mercados regulamentados de valores mobiliários, a Instrução CVM n 461/2007, vedou a possibilidade de que as entidades administradoras do mercado organizado de bolsa concedam esse tipo de acesso aos seus sistemas de negociação.

Tal possibilidade, no entanto, ficou expressa para as entidades administradoras do mercado de balcão organizado. Até o momento, as consequências dessa permissão não puderam ser sentidas, pois, em vista da vedação à dupla listagem, o mercado de balcão é pouco relevante no âmbito do mercado de ações.

${ }^{83}$ Faz-se referência ao que a BM\&FBOVESPA denomina Acesso Direto ao Mercado Tradicional. No mercado de ações é a única forma possível de acesso eletrônico ao mercado. No entanto, no segmento de derivativos já há outras formas de acesso eletrônico em funcionamento, todas intermediadas. 
Adicionalmente, ainda que assim não fosse, o mercado de balcão em que são negociadas ações também é administrado pela BM\&FBOVESPA ${ }^{84}$, que optou por não permitir o acesso direto puro, ou não intermediado aos seus sistemas.

\subsection{Problemas relacionados ao Acesso Eletrônico ao Mercado}

Dois tipos de risco são especialmente relevantes quando se trata do acesso eletrônico ao mercado: o risco de negociação e o risco de crédito.

O risco de negociação pode ser visto como um risco para o intermediário, se relacionando ao cumprimento das normas relativas ao envio de ordens e aos negócios executados em nome de seus clientes que acessam eletronicamente o mercado.

O risco de crédito, por sua vez, é aquele incorrido pelo intermediário quanto à liquidação financeira das transações efetuadas pelos seus clientes.

\subsubsection{Risco de Negociação}

Já se disse que o intermediário é responsável por todas as ordens inseridas nos sistemas de negociação acessados eletronicamente por seus clientes. Isso significa que cabe ao intermediário o cumprimento de todas as normas relativas ao processo de negociação, inclusive aquelas que visem a evitar práticas abusivas, bem como que o não cumprimento dessas normas o sujeita às sanções previstas naquelas normas.

Tais normas são fixadas não apenas pelos reguladores, mas também pelos autorreguladores do mercado. Cabe lembrar que as entidades autorreguladoras, em geral, não dispõem de poder regulatório sobre as pessoas não autorizadas por elas a operar, de forma que normalmente exigem o cumprimento estrito das regras de concessão de acesso eletrônico por parte dos intermediários e fixam regras para que os intermediários realizem o monitoramento das operações feitas pelo cliente.

Nesse contexto o contrato firmado entre o investidor e o intermediário adquire uma relevância ainda maior, porque é por meio dele que os intermediários buscarão assegurar-se de que seus clientes com acesso eletrônico cumprirão as regras do mercado.

\footnotetext{
84 A possibilidade de que uma mesma entidade administre dois mercados organizados está expressa na Instrução CVM nº 461/2007, artigo 12.
} 
Considerando, ainda, que para a maioria dos intermediários o acesso eletrônico é uma forma adicional de oferecimento de acesso que, portanto convive com a forma tradicional, os intermediários fixam procedimentos específicos de acompanhamento das operações cursadas eletronicamente, visando a impedir que sejam usadas para a prática de irregularidades.

Quanto aos riscos decorrentes da negociação eletrônica, um estudo desenvolvido por Aitken et alli (2009) sobre a eficiência de mercado e a manipulação na negociação é bastante alentador para os intermediários. As conclusões são de que quanto mais modernos os instrumentos de fiscalização de operações no ambiente de negociação, menos sujeito a manipulações estará o mercado, o que não deixa de ser intuitivo.

Adicionalmente, o estudo conduzido permitiu concluir que o acesso eletrônico ao mercado, ao facilitar a utilização de algoritmos de negociação, torna mais difícil a ocorrência de manipulações de mercado. Isso ocorre porque, ao utilizar algoritmos de negociação, os investidores diminuem a chance de que um manipulador seja bem sucedido, já que é mais difícil fazer armadilhas para algoritmos. ${ }^{85}$

\subsubsection{Risco de Crédito}

O risco de crédito, nesse contexto, é o risco de o intermediário ser responsável financeiramente pelos negócios de seus clientes. Isso significa que se um investidor não puder entregar os ativos que vendeu ou pagar pelos que comprou, o intermediário terá que fazer isso em seu lugar.

Na maioria dos países, a responsabilidade primária pelo controle de crédito e gerenciamento de riscos é do intermediário (pessoa autorizada a operar). Quando a ordem passa pelo intermediário antes de atingir o sistema de negociação, há tempo para que o intermediário faça as verificações necessárias, referentes à gestão de riscos e controles prénegociação.

Ressalte-se que o tempo disponível para a implementação de tais controles é mensurado em milisegundos, mas se os investidores são capazes de desenvolver sistemas que enviam milhares de ordens por segundo, o intermediário também deve ser capaz de ter

${ }^{85}$ In AITKEN, Michael J. et alli. "Trade Based Manipulation and Market Efficiency: A Cross-Market
Comparison", 2009, p. 18. $-56-$ 
sistemas eletrônicos que possam fazer as checagens necessárias na mesma velocidade. É parte do ônus de oferecer acesso eletrônico aos clientes.

Não se pode negar que o acesso eletrônico patrocinado aumenta a dificuldade da gestão de risco por parte do intermediário, pois como visto, ele não tem a possibilidade de interferência no processo antes da negociação.

Tal impossibilidade aumenta a necessidade de que os controles prénegociação sejam rigorosos e impõe um desafio não só aos intermediários, mas também aos sistemas de negociação que devem ser capazes de dar respostas muito rápidas aos intermediários para que seus controles pós-negociação sejam eficazes ${ }^{86}$.

${ }^{86}$ Recentes discussões sobre o papel dos ambientes de negociação na gestão de riscos têm focado a necessidade de que as informações cheguem rápida e completamente aos intermediários. Embora algumas bolsas sejam conhecidas pela rapidez com que entregam informações sobre os negócios executados, há bolsas em que essas informações demoram alguns minutos para chegarem aos intermediários, o que prejudica o seu controle de riscos, sobretudo num sistema de negociação que comporta a realização de milhares de operações por segundo. Nesse cenário é difícil de se imaginar o estrago que um "high frequency trader" pode ocasionar se uma falha qualquer determinar a contínua execução de ordens num sentido ou noutro. Em situações como essa o intermediário deve ser capaz de interferir, impedindo o prosseguimento das negociações. 


\section{O Papel do Intermediário enquanto Provedor de Acesso Eletrônico ao Mercado}

A teoria da intermediação encontra seus fundamentos na existência de custos de transação e de assimetria informacional, imperfeições do mercado que, se desaparecessem, poderiam igualmente levar ao desaparecimento dos intermediários ${ }^{87}$.

A assimetria informacional está relacionada à incapacidade dos agentes econômicos de processar, interpretar e utilizar informações, ainda que elas sejam de domínio coletivo. Além disso, como alertou Akerlof (1970), os agentes econômicos têm níveis de informação distintos quando negociam: o vendedor tende a conhecer melhor o produto do que o comprador ${ }^{88}$.

No mercado secundário de valores mobiliários, tanto os custos de transação quanto a assimetria informacional têm sido reduzidos nos últimos anos ${ }^{89}$, o que se pode atribuir, pelo menos em parte, à introdução dos sistemas de negociação eletrônica. Poderia ser o início do fim da existência dos intermediários?

Pode-se responder essa questão de diversas maneiras. Uma delas é pensando nas razões que levam os agentes a procurarem intermediários.

Os intermediários são indubitavelmente prestadores de serviços e cobram para executá-los. Racionalmente, uma pessoa não deveria estar disposta a pagar por um serviço que ela mesma poderia executar com igual qualidade.

À primeira vista, é isso que pode estar acontecendo no mercado secundário de valores mobiliários, onde, como visto, já é possível que o investidor acesse diretamente os sistemas de negociação, prescindindo do intermediário. Resta saber se isso interessa ao mercado.

\footnotetext{
${ }^{87}$ In ALLEN, Franklin. e SANTOMERO Anthony M. . "What do financial intermediaries do?" Journal of Banking and Finance, n 25, 2001, p. 272.

${ }^{88}$ In AKERLOF, George A. "Market for 'Lemons': Quality Uncertainty and Market Mechanism". The Quarterly Journal of Economics, vol. 84, nº 3, 1970, p. 488.

${ }^{89}$ In ALLEN e SANTOMERO, ob. cit., p. 272: "There has been a significant reduction in transaction costs and asymmetric information in recent decades. Over this same period, the importance of traditional banks that take deposits and make loans has, by some measures, been reduced. However, other forms of intermediaries such as pension funds and mutual funds have grown significantly. In addition, new financial markets such as financial futures and options have developed, as markets for intermediaries rather than for individuals. All of this seems, if not contrary to standard theory, as least inconsistent with it."
} 
No passado, quando os direitos de negociar estavam atrelados à propriedade de um título patrimonial da bolsa, por exemplo, a discussão sobre a necessidade do intermediário no processo de negociação não se colocava.

No contexto atual, quebrado o referido vínculo e aberta a possibilidade tecnológica de concessão de acesso eletrônico não intermediado, passa-se a discutir o papel do intermediário no mercado.

Já se disse que atualmente os investidores por meios de seus terminais de computador, encaminham ordens que em frações de segundos são executadas nos ambientes de negociação. Embora na maioria das vezes exista, a presença do intermediário sequer é notada dada a velocidade em que as transações ocorrem.

À medida que essa forma de negociar se dissemina, é possível que o próximo passo desejado pelo investidor seja o acesso direto ao mercado sem intermediação, afinal de contas, eliminando o intermediário também se elimina o pagamento de taxas de corretagem.

Ocorre, porém que esse raciocínio é por demais simplista, ainda que possa fazer sentido aos olhos de alguns. A presença do intermediário é fundamental no mercado secundário de valores mobiliários porque o serviço por ele prestado tem valor, não só preço.

Para utilizar o termo empregado por Coffee (2006), o intermediário é um verdadeiro "gatekeeper", ou seja, o intermediário está na cadeia de negociação para assegurar o cumprimento das normas e prevenir a ocorrência de irregularidades e, como tal, seu papel é essencial ${ }^{90}$.

Dada essa essencialidade, como explicar a existência de acesso direto não intermediado no mercado de valores mobiliários?

No mercado há outros "gatekeepers", notadamente as entidades administradoras do mercado organizado, que ao concederem acesso eletrônico não

\footnotetext{
${ }^{90}$ In COFFEE JR, John C. "Gatekeepers - The Professions and Corporate Governance", Oxford University Press, 2006, p. 2 "(...) the gatekeeper may be a professional who is positioned so as to be able to prevent wrongdoing by withholding necessary cooperation or consent. For example, an investment banking firm can refuse to underwrite the issuer's securities if it finds that the issuer's disclosures are materially deficient; similarly, an auditor or an attorney who discovers a serious problem with a corporate client's financial statements or disclosures can prevent a merger from closing by declining to deliver an opinion that is a necessary precondition for the transaction. In this first sense, the gatekeeper is a private policeman who has been structured into the process to prevent wrongdoing. By withholding its approval, is closes the gate, typically denying the issuer access to the capital markets. So defined, even the board of directors can be seen as gatekeepers, and the Securities and Exchange Commission certainly is a public gatekeeper".
} 
intermediado a alguns investidores, assumem o ônus de desenvolverem as funções do intermediário no processo de negociação.

Isso dá a noção da relevância do papel do intermediário, mesmo quando ausente, suas funções devem ser desempenhados por quem o substitua.

\subsection{As funções do intermediário num mercado acessado eletronicamente}

Num mercado acessado eletronicamente, a atividade do intermediário muda sensivelmente. As mesas de operações perdem importância relativa, já que boa parte das ordens é colocada no sistema pelos próprios investidores, e as áreas de tecnologia da informação, controles internos e gestão de riscos ganham mais destaque.

Isso é compatível com os desafios que a negociação eletrônica impõe aos intermediários e se coaduna com a tese defendida por Allen e Santomero (2001), segundo os quais o entendimento desse novo cenário requer a formulação de teorias que valorizem o risco de negociação, a gestão de riscos e os custos de participação (entendidos como o conhecimento necessário para atuar num mercado altamente sofisticado) como as principais razões de existência dos intermediários modernos.

A estrutura organizacional dos intermediários mostra a importância adquirida por algumas atividades que, não coincidentemente, se relacionam aos principais desafios dos intermediários advindos da implantação do acesso eletrônico.

\subsubsection{Gestão do Risco de Negociação}

$\mathrm{Na}$ maioria das vezes o acesso eletrônico ao mercado é concedido ao investidor por decisão exclusiva do intermediário, o que não significa que as entidades administradoras do mercado e os reguladores não fixem requisitos mínimos a serem verificados pelo intermediário antes da concessão de referido acesso.

Esses requisitos tendem a variar em função do tipo de acesso franqueado ao investidor (roteamento ou acesso patrocinado), sendo mais rígidos se mais "liberdade" for dada ao investidor ${ }^{91}$.

\footnotetext{
${ }^{91}$ É comum que as entidades administradoras do mercado de bolsa só permitam o tipo de acesso eletrônico patrocinado a investidores institucionais.
} 
O Relatório da OICV/IOSCO sobre as Políticas de Acesso Eletrônico ao Mercado ${ }^{92}$ revela que a maioria dos intermediários, antes de conceder acesso eletrônico a um investidor, considera os seguintes fatores:

$\checkmark$ Familiaridade com as regras do mercado;

$\checkmark$ Experiência financeira;

$\checkmark$ Existência de sanções por irregularidades cometidas no mercado;

$\checkmark$ Evidências de um bom histórico no mercado;

$\checkmark$ Capacidade de cumprimento de orientações sobre crédito e risco;

$\checkmark$ Níveis mínimos de ativos sob administração;

$\checkmark$ Estratégia de negociação com volumes esperados.

No mesmo documento a OICV/IOSCO relata que em muitos países o acesso eletrônico só é concedido a instituições financeiras, ou entidades equiparadas a instituições financeiras e mesmo quando isso não é exigido, algum nível de sofisticação do investidor é normalmente posto com requisito à concessão do acesso.

As pesquisas da OICV/IOSCO apontam que poucos intermediários estariam dispostos a conceder acesso eletrônico a investidores de varejo ${ }^{93}$.

A gestão do risco de negociação está muito relacionada aos contratos celebrados entre intermediários concedentes e investidores concessionários do acesso eletrônico, contratos esses que estabelecem claramente as responsabilidades de cada uma das partes contratantes. Tendo em vista que os intermediários são sempre responsáveis pelos negócios realizados, a maioria deles firma contratos escritos com seus clientes de forma a resguardar-se de eventuais descumprimentos de normas.

São cláusulas comuns aos mencionados contratos, aquelas que tratam:

dos direitos e deveres das partes contratantes, incluindo declarações de que o cliente aceita a responsabilidade decorrente do acesso eletrônico, principalmente no que concerne aos códigos de negociação e à liquidação física e financeira das operações;

\footnotetext{
92 "Policies on Direct Electronic Access - Consultation Report"- OICV-IOSCO Technical Committee, 2009.

${ }^{93}$ No Relatório da OICV/IOSCO sobre o acesso eletrônico o encaminhamento de ordens por meio da Internet não foi considerado uma das forma de acesso eletrônico. Penso não haver dúvidas de que no Brasil o "home broker" deve ser considerado uma forma de acesso eletrônico seja porque ele atende ao requisito principal do conceito desse tipo de acesso, qual seja, a ausência de interferência humana no caminho da ordem colocada pelo investidor até sua inserção no sistema de negociação, seja porque de fato se trata de um sistema de roteamento de ordens, assim tratado, inclusive no Regulamento de Operações da Bolsa.
} 
$\checkmark$ da segurança física e tecnológica, abrangendo a identificação do usuário, senhas, códigos de autenticação, evitando o acesso não autorizado;

$\checkmark$ dos limites financeiros para as operações que uma vez ultrapassados ensejam a rejeição das ordens pelo sistema, bem como o estabelecimento de limites máximos por ordem e/ou por usuário;

$\checkmark$ do estabelecimento de garantias, indenização e encargos;

$\checkmark$ das condições para a inserção de ordens ou relativas a ocorrência de erros operacionais, por exemplo, bem como o estabelecimento de restrições, tais como o direito de suspensão do serviço ou de rejeitar ou cancelar ordens;

$\checkmark$ do uso de sistemas de mensageria padronizados (SWIFT ou FIX);

$\checkmark$ do conhecimento das leis e regras que regem a negociação e o comprometimento em segui-las;

$\checkmark$ do requisito de que os usuários do sistema sejam autorizados, qualificados e competentes.

Apenas a existência de uma relação contratual ente o intermediário e o cliente investidor não é suficiente para assegurar o cumprimento das normas, por isso os intermediários devem ter procedimentos e políticas para monitorar os negócios realizados pelos clientes.

Embora a atividade de monitoramento não deva estar relacionada apenas aos clientes que se utilizem do acesso eletrônico, ela adquire ainda maior relevância nesse cenário porque exige um nível mais sofisticado de controles em razão do número de operações, dos volumes e da complexidade dos negócios realizados ${ }^{94}$.

Nesse contexto é recomendável que os intermediários disponham de ferramentas eletrônicas de gestão de riscos de pré-negociação. A gestão desse risco se dá por meio da checagem das ordens antes que elas sejam encaminhadas para os sistemas de negociação eletrônica.

Os filtros têm sido mais comumente utilizados para esse fim ${ }^{95}$. Como o próprio nome sugere, os filtros têm a capacidade de impedir o prosseguimento da ordem dada pelo cliente caso ela não esteja de acordo com determinados parâmetros.

\footnotetext{
${ }^{94}$ Refere-se a operações combinadas, denominadas estratégias.

${ }^{95}$ Um dos desafios das áreas de tecnologia da informação é a criação de sistemas que consigam proporcionar conforto para a gestão de riscos sem comprometer a velocidade da negociação.
} 
Há filtros sobre o objeto da negociação (valor, quantidade, mercado, instrumento ou posição), filtros sobre como a negociação é feita (tipo de ordem, fluxo, tempo) e filtros que detectam quem está negociando.

Quanto mais combinados entre si eles forem, maior a complexidade da política de gestão de riscos do intermediário, cabendo a ele a fixação de parâmetros e a monitoração do sistema.

\subsubsection{A Gestão do Risco de Negociação no Brasil}

As práticas relacionadas à gestão de risco de negociação no Brasil se assemelham às adotadas pelos intermediários no mundo todo, começando pela celebração de contratos entre o intermediário e o investidor a quem será concedido o acesso eletrônico ao mercado.

Em geral os contratos, embora não sejam exatamente padronizados, apresentam relativa uniformidade. São cláusulas comuns a esses contratos:

$\checkmark$ sujeição às regras e parâmetros de atuação do intermediário ${ }^{96}$, bem como às normas que regem o mercado;

$\checkmark$ responsabilidade do cliente quanto ao uso de senhas de acesso e da assinatura eletrônica e compromisso de mantê-las sob sigilo;

$\checkmark$ irreversibilidade das operações autorizadas por meio do uso de assinatura eletrônica;

$\checkmark$ direito de o intermediário recusar a efetivação das transações quando constatar que a operação colocará em risco o cumprimento por parte do cliente;

$\checkmark$ direito de cancelamento de ordens por parte do intermediário, especialmente quando o cliente estiver inadimplente;

$\checkmark$ estabelecimento de limites de negociação;

$\checkmark$ responsabilidade do cliente pelo aporte de garantias exigidas e pelo pagamento das taxas e tributos decorrentes de suas negociações;

${ }^{96}$ Regras e Parâmetros de Atuação é o documento que estabelece os procedimentos do intermediário relativos ao recebimento, ao registro, à recusa, ao prazo de validade, à prioridade, à execução, à distribuição dos negócios e ao cancelamento das ordens de operações recebidas de seus clientes, bem como os relativos à liquidação das respectivas operações e custódia dos títulos. 
$\checkmark$ assunção, pelo cliente, da responsabilidade, civil e criminal, decorrente da prestação de informações falsas ao intermediário;

$\checkmark$ declaração de conhecimento das regras e da legislação envolvidas na negociação de valores mobiliários;

$\checkmark$ isenção de responsabilidade do intermediário por falhas no sistema de conexão por culpa de terceiros (companhia telefônica, por exemplo).

A gestão de riscos pré-negociação, no entanto não pode se restringir à existência de contratos. Na realidade esses contratos podem não ser mais do que mera formalidade se não houver controles eficientes para monitorar a atividade do cliente. Esse monitoramento não se faz sem que se conheça o cliente ${ }^{97}$.

Conhecer o cliente significa identificá-lo perfeitamente e ter acesso a informações sobre suas características enquanto investidor, que determinam os negócios feitos por ele.

No Brasil, o principio do "conheça seu cliente" está intimamente relacionado ao cadastro do cliente junto ao intermediário. As informações cadastrais, além de cumprirem uma exigência regulatória, tem importante função na gestão de riscos de pré negociação, na medida em que permitem a criação e implementação de critérios para o uso de filtros (ou outras formas de controle) aos quais serão submetidas as ordens enviadas pelos investidores, antes de serem encaminhadas para os sistemas de negociação.

\subsubsection{Gestão de Risco de Crédito}

É muito comum que as entidades administradoras de mercado estabeleçam princípios para a gestão de risco de crédito, visto como uma das principais questões do acesso eletrônico ao mercado. Além disso, o fornecimento de ferramentas adequadas para a gestão desse risco pode ser um novo negócio para essas entidades e/ou uma forma de diferenciá-las em ambientes mais competitivos.

O estabelecimento de princípios gerais para a gestão do risco de crédito pelas entidades administradoras permite que os intermediários tenham flexibilidade para

\footnotetext{
${ }^{97}$ O princípio denominado "Conheça seu Cliente" normalmente é associado a regras de prevenção à lavagem de dinheiro. Aqui está sendo utilizado numa abordagem mais ampla, abrangendo não apenas os procedimentos relativos à lavagem de dinheiro, mas também como instrumento para que o intermediário tenha compreensão das características do investidor e das suas necessidades.
} 
implantar os controles que julguem adequados em função de sua estrutura e de suas características.

Por outro lado, a inexistência de parâmetros objetivos pode contribuir para a gestão menos rigorosa do risco de crédito, de forma que algumas entidades administradoras de mercado ultrapassam a fixação de princípios e estabelecem requisitos a serem preenchidos pelos intermediários.

Independentemente da abordagem utilizada pela entidade administradora do mercado, os intermediários fazem a gestão do risco de crédito com base nos seguintes critérios que devem ser considerados em conjunto:

$\checkmark$ análise do potencial dos investidores em termos de histórico e solvabilidade;

$\checkmark$ controles de risco pré-negociação; e

$\checkmark$ controles de risco pós-negociação.

O perfil de risco do investidor é determinado pela análise das informações que estão disponíveis sobre ele. Trata-se da principal ferramenta de gestão de risco de crédito porque os controles de risco são implementados em função dessas informações.

Os controles de risco que antecedem a execução da ordem estão normalmente relacionados à prevenção à colocação de ordens erradas, a emissão de alertas quando detectada uma "atividade anormal" ou de filtros que limitem o tamanho das ordens, por exemplo.

Os sistemas de controle de risco devem ser capazes de responder imediatamente a um aumento do risco do investidor referenciado em seu padrão de negociação, de forma que a quebra desse padrão implique a interrupção do fluxo de ordens.

Note-se que controles de pré-negociação só podem ser utilizados se o acesso eletrônico ao mercado se der com a utilização da infraestrutura do intermediário, por essa razão o uso de filtros pré-negociação é mais difundido entre os intermediários que concedem o acesso eletrônico por meio do roteamento de ordens.

Os controles de risco pós-negociação devem informar qual o risco assumido pelo cliente uma vez feita a operação. Os intermediários em geral têm algum nível de controle de risco pós-negociação, mas há que se considerar que essa atividade atinge muita complexidade num mercado em que a oferta de produtos é crescente e há nítida sofisticação dos instrumentos financeiros. 


\subsubsection{Gestão de Risco de Crédito no Brasil}

No Brasil, a liquidação das operações realizadas no mercado acionário ocorre na $\mathrm{CBLC}^{98}$, que é responsável pelos serviços de guarda centralizada, compensação e liquidação das operações realizadas nos mercados da BM\&FBOVESPA, no segmento de ações.

A liquidação das operações ocorre de acordo com uma cadeia de responsabilidades que envolve desde a CBLC até o investidor e pode ser resumida da seguinte maneira:

$\checkmark$ a CBLC é responsável pelo gerenciamento e controle do seu risco de crédito com os Agentes de Compensação ${ }^{99}$;

$\checkmark$ os Agentes de Compensação são responsáveis pelo gerenciamento e controle do respectivo risco de crédito com os Participantes de Negociação, ou seja, com os intermediários ${ }^{100}$, e vice-versa;

$\checkmark$ os Intermediários são responsáveis pelo gerenciamento e controle do respectivo risco de crédito com os Investidores e vice-versa.

Cada um dos participantes da cadeia deve identificar e mensurar o risco de crédito ao qual está exposto e estabelecer a forma de cobertura ou transferência desse risco por meio da obtenção de garantias ou outra forma de proteção. Nesse processo desempenha importante papel o Limite Operacional que é atribuído pela CBLC aos Agentes de Compensação, com base nas garantias por ele depositadas junto a ela.

O Limite Operacional atribuído aos Agentes de Compensação será por eles repassado aos intermediários com base em critérios de alocação definidos nos contratos firmados entre as parte e na avaliação do intermediário feita pelo Agente de Compensação. Tais limites podem ser elevados ou reduzidos a qualquer tempo, mas devem sempre ser

\footnotetext{
${ }^{98}$ Após a desmutualização da Bovespa, a CBLC passou a ser uma subsidiária integral da Bovespa Holding S.A.. Com a reorganização societária que criou a BM\&FBOVESPA S.A., a estrutura da CBLC foi incorporada pela Bolsa.

${ }^{99}$ Agente de Compensação é a instituição responsável, como contraparte perante seus clientes e a CBLC, pela liquidação e pela prestação de garantias referentes às operações própria e/ou de seus clientes. Os Agentes de Compensação podem ser sociedades corretoras, bancos comerciais ou múltiplos, bancos de investimento, sociedades distribuidoras e outras instituições a critério da CBLC que preencham os critérios fixados nos seus Procedimentos Operacionais para atuarem como tal.

${ }^{100}$ Embora os agentes de compensação também sejam intermediários, aqui se utiliza a expressão Participante de Negociação como sinônimo de intermediário para dar mais clareza à cadeia de liquidação no âmbito deste trabalho.
} 
informados à CBLC, uma vez que as operações que excedam os limites operacionais concedidos não são passíveis de aceitação pela CBLC.

Note-se que devido à responsabilidade do intermediário pela liquidação das operações efetuadas pelos seus clientes, é extremamente importante o controle do risco de crédito de cada investidor.

Esse controle é normalmente feito em cada instituição intermediária por um Departamento de Riscos, cujo objetivo é fazer a gestão de riscos e o reporte à administração do intermediário.

A adequada gestão do risco de crédito se dá pelo acompanhamento e monitoramento em tempo real das operações realizadas pelos clientes e sua respectiva exposição e da possibilidade de intervenção quando necessária a mitigação de riscos, o que preserva o intermediário, mas também se traduz num ganho para o próprio investidor que tem seu risco controlado como um subproduto da intermediação.

\subsection{Ausência do Intermediário}

Ainda que a acesso eletrônico intermediado seja prevalecente no mercado de valores mobiliários, existe a possibilidade de que o acesso ao mercado se dê sem a interferência do intermediário, como visto anteriormente, o que seria uma prova da dispensabilidade do intermediário.

É fato que os arranjos tecnológicos permitem que os investidores acessem diretamente o mercado, mas também é fundamental dizer que as funções desempenhadas pelos intermediários na gestão de riscos não podem ser simplesmente abandonadas nas hipóteses em que tal forma de acesso ocorre.

Dessa forma, na ausência do intermediário tais funções passam a ser de responsabilidade da entidade administradora do mercado, ou seja, do ambiente de negociação que proporcionou o acesso direto.

Os custos e complexidades desses controles podem tornar desinteressante a concessão desse tipo de acesso ou, pelo menos, restringir muito o número de investidores para os quais interessaria às entidades que o acesso direto fosse concedido.

Conquanto as imposições regulatórias sejam importantes, como se verá adiante, muito mais importante é o valor que a presença do intermediário agrega para o mercado como um todo, pois mesmo para os agentes que poderiam prescindir da 
intermediação, a sua existência aumenta a segurança e confiabilidade de que as transações são feitas com base em princípios de equidade e transparência e obedecem a controles de risco adequados. 


\section{A Regulação aplicável à Atividade de Intermediação no contexto da Negociação Eletrônica}

Ao introduzir a questão da Regulação Financeira, Yazbek (2007), afirmou que:

“... tanto a proteção dos agentes não financeiros individuais, geralmente hipossuficientes perante as instituições que lhes prestam serviços, quanto a tutela do sistema financeiro fogem à mera negociabilidade ou a soluções organizativas "privadas” - a natureza daqueles riscos dificulta a criação de mercados para a sua negociação ou a sua mera internalização. Impõe-se assim, para a proteção dos clientes e do sistema financeiro (do conjunto de relações e de instituições interligadas), a regulação externa, usualmente estatal, das atividades financeiras. Esse tipo de justificativa, aliás, não vale exclusivamente par a regulação financeira. Cada vez mais a intervenção do Estado como regulamentador e fiscalizador de determinadas atividades se encontra relacionada àquele tipo de diagnóstico - as atividades e a forma de integração dos agentes privados geram riscos que a sociedade inteira, e não apenas aqueles agentes, precisam suportar. „101

Se a atividade financeira, por si só, já requer a intervenção do Estado, no contexto do acesso eletrônico ao mercado, essa intervenção parece ainda mais necessária. Isso se deve às pressões competitivas que geram os investidores a resistirem à implantação de medidas de controle, gerando um potencial "afrouxamento" 102 das regras, situação que já foi relatada pelos intermediários em pesquisas da OICV/IOSCO. ${ }^{103}$

A redução do nível das exigências da regulação, seja ela proveniente dos órgãos reguladores ou autorreguladores, não vai ao encontro das necessidades do mercado como um todo, caracterizando-se ao contrário, como uma pressão de um grupo restrito de investidores, com interesses bastante específicos.

\footnotetext{
${ }^{101}$ In YAZBEK, Otavio. “Regulação do Mercado Financeiro e de Capitais”, Elsevier, 2007. pp. 175-176.

102 O dito "afrouxamento" é conhecido no mercado pela expressão em inglês "race to the bottom".

103 “Policies on Direct Electronic Access - Consultation Report”- OICV-IOSCO Technical Committee, 2009.
} 
Essas pressões foram identificadas, por exemplo, como originárias dos negociadores de alta frequência, para os quais um segundo é uma eternidade. Alguns deles insistem em que suas ordens não sejam submetidas aos sistemas de controle prénegociação porque eles aumentam a latência para a execução.

Esse tipo de comportamento certamente tem influenciado o regulador norteamericano que já se pergunta se "negociar mais rápido é negociar melhor". Talvez o seja para o negociador de alta frequência, mas há sérias dúvidas de que seja melhor para o mercado como um todo.

\subsection{Acesso Eletrônico e Regulação}

Ao mesmo tempo em que é um dos mercados onde se observa mais claramente a chamada globalização, o mercado financeiro também apresenta as mais diversas características e estrutura pelos diversos países.

A forma como se estruturou o mercado secundário não é exceção a essa regra. Apesar disso, percebendo o potencial para a chamada arbitragem regulatória ${ }^{104}$, a OICV/IOSCO tem feito um grande esforço no sentido da uniformização da regulação, por meio do estabelecimento de princípios que devem nortear a atividade regulatória nos países membros.

Em 2003 a OICV/IOSCO divulgou 30 Princípios para Regulação dos Valores Mobiliários para o cumprimento de três objetivos básicos:

$\checkmark$ proteção aos investidores: investidores devem ser protegidos de práticas enganosas, manipulativas ou fraudulentas, tais como o "insider trading",105 e o "front running" ${ }^{106}$, bem como do desvio de seus recursos;

\footnotetext{
${ }^{104}$ A arbitragem regulatória consiste na análise por parte de um investidor dos vários ambientes regulatórios onde possa operar de forma a optar por aquele que se revele mais vantajoso. A expressão se aplica a uma escolha entre regimes com diferentes exigências legais e controle por parte de entidades reguladoras.

105 In PROENÇA, José Marcelo Martins."Insider Trading - Regime jurídico do uso de informações privilegiadas no mercado de capitais", Quartier Latin, 2005, p. 41: "A expressão insider trading, pela qual designado o tema deste trabalho, é originária do direito americano e, hoje, internacionalmente conhecida e consagrada para nomear transações desleais, porque insidiosas, realizadas, no âmbito do mercado de capitais, pelos detentores de informações privilegiadas, desconhecidas dos demais investidores."

${ }^{106}$ In NORONHA, Ilene Patrícia de. “Aspectos Jurídicos da Negociação de Valores Mobiliários via Internet”, in Direito e Internet - Aspectos Jurídicos Relevantes, Quartier Latin, 2 ${ }^{\mathrm{a}}$ Ed., 2005, p. 229. Acerca do Frontrunning usa o seguinte exemplo: “...um operador recebe determinada ordem e, antes de executá-la, registra outra, em seu nome ou no de um 'laranja', executando-a em primeiro lugar, invertendo a operação contra o cliente que lhe deu a ordem."
} 
garantia de mercados justos, eficiente e transparentes: prevenção a práticas de negociação inadequadas, que privilegiem alguns investidores em detrimento de outros, tais como a manipulação de mercado que deve ser detectada, impedida e punida. A regulação deve assegurar o correto tratamento de ordens e um processo de formação de preços confiável.

$\checkmark$ redução do risco sistêmico: a regulação deve objetivar reduzir o risco de quebra dos intermediários, inclusive por meio de requisitos de capital e de controles de risco). Em caso de quebra do intermediário, a regulação deve procurar reduzir os efeitos dessa quebra, e, sobretudo, tentar isolar o risco da instituição quebrada, evitando contaminações do sistema.

Para consecução dos objetivos a OICV/IOSCO julga que a regulação deve traduzir os Princípios em normas concretas de proteção à integridade do mercado de valores mobiliários.

Especificamente no que diz respeito à atividade de intermediação, os Princípios são os seguintes:

$\checkmark$ Princípio 21: A regulação deve fixar padrões mínimos para o acesso de intermediários ao mercado.

$\checkmark$ Princípio 22: Devem ser estabelecidos requisitos mínimos de capital inicial e capital para operação dos intermediários, bem como outros requisitos de caráter prudencial que possam fazer frente aos riscos incorridos pelos intermediários.

$\checkmark$ Princípio 23: Deve-se exigir que os intermediários cumpram requisitos de padrões de organização e conduta operacional que visem a proteger os interesses dos clientes e a assegurar a adequada administração de riscos, de tal forma que o intermediário assuma a responsabilidade primária por essas matérias.

$\checkmark$ Princípio 24: Deve haver um procedimento para se lidar com a quebra de um intermediário, de forma a minimizar danos e perdas de investidores e conter o risco sistêmico.

A supervisão dos intermediários deve estar focada nas áreas onde estão os maiores riscos, daí os Princípios da OICV/IOSCO afirmarem que a preocupação dos reguladores deve ser elaborada no sentido de evitar os riscos de que a (i) incompetência ou o gerenciamento inadequado de riscos levem a falhas de execução ou de liquidação; (ii) violações de conduta levem à indevida apropriação dos recursos do cliente, o uso indevido das ordens do cliente para satisfazer os propósitos do intermediário ("front running"), 
manipulações e outras irregularidades cometidas na negociação, ou mesmo a fraude da parte do intermediário ou de seus prepostos; e (iii) a insolvência de um intermediário resulte em perdas para o cliente, sejam elas de recursos, valores mobiliários ou de oportunidades de negócios, além de reduzirem a confiança no mercado no qual o intermediário está inserido.

Como se nota, os princípios da OICV/IOSCO continuam com plena aplicabilidade no mercado acessado eletronicamente. No entanto, eles parecem não ser suficientes para assegurar a adoção, tanto por parte das entidades administradoras de mercado, quanto pelos próprios intermediários, de medidas que visem a evitar riscos indevidos.

Ironicamente, a preocupação agora é de que os investidores com acesso eletrônico ao mercado possam, intencionalmente ou não, causar perturbações no mercado ou empreender estratégias de negociação que envolvam elementos de fraude ou manipulação. Quanto à segurança e integridade do mercado há grande preocupação com os acessos não autorizados.

Em função de todos esses problemas, a OICV/IOSCO submeteu à audiência pública alguns possíveis Princípios que venham a nortear a regulação concernente aos acessos eletrônicos ${ }^{107}$. São eles:

$\checkmark$ Princípio proposto 1: Clientes com acesso eletrônico ao mercado devem atender a padrões mínimos, incluindo recursos financeiros apropriados; familiaridade com e capacidade de cumprir as regras do mercado; conhecimento do sistema de inserção de ordens que o cliente for autorizado a utilizar; e proficiência no uso desse sistema.

$\checkmark$ Princípio proposto 2: Deve haver um contrato registrado que vincule juridicamente o intermediário e o cliente. A natureza e detalhes desse contrato devem ser adequados ao tipo de serviço que ele regula.

$\checkmark$ Princípio proposto 3: Onde é permitido ao cliente do intermediário sub-delegar o seu direito de acesso eletrônico ao mercado para outra parte (sub-delegado), o intermediário deve procurar se assegurar de que os contratos com o seu cliente lhe permitam a identificação do sub-delegado quando houver requisição das autoridades de mercado.

107 "Policies on Direct Electronic Access - Consultation Report"- OICV-IOSCO Technical Committee, 2009. 
$\checkmark$ Princípio proposto 4: Objetivando facilitar a supervisão de mercado, quando solicitados, os intermediários devem informar prontamente às autoridades de mercado a identidade dos clientes que tenham acesso eletrônico ao mercado.

$\checkmark$ Princípio proposto 5: As entidades administradoras do mercado devem dar às pessoas autorizadas a operar, acesso a informações pré e pós negociação (em tempo-real) necessárias para a implementação de controles de risco e monitoramento apropriados.

$\checkmark$ Princípio proposto 6: Mercados que permitam o acesso eletrônico (por roteamento ou patrocinado) devem ter regras que busquem assegurar que os intermediários que concedem acesso eletrônico a seus clientes tenham controles de pré-negociação para administrar adequadamente o risco, visando a negociações em condições justas.

$\checkmark$ Princípio proposto 7: Intermediários (incluindo as Câmaras de Compensação e Liquidação) devem dispor de controles regulatórios e financeiros, dentre os quais filtros pré-negociação automatizados, os quais possam limitar ou impedir um clientes de colocar uma ordem que exceda os limites de posição ou de crédito atribuídos a esse cliente.

$\checkmark$ Princípio proposto 8: Intermediários (incluindo as Câmaras de Compensação e Liquidação) devem ter sistemas técnicos e operacionais adequados para administrar os sistemas de acesso eletrônico ao mercado.

Note-se que as preocupações da OICV/IOSCO, e por consequência dos reguladores, estão relacionadas aos controles exercidos pelos intermediários (e os sistemas que os possibilitam) para mensurar e administrar os riscos envolvidos na negociação iniciada por meio do acesso eletrônico ao mercado.

Indubitavelmente, os reguladores e autorreguladores desempenharão papel importante para assegurar que os riscos sejam adequadamente administrados, evitando que tenham que ser suportados por aqueles que não os geraram. 


\subsubsection{A Regulação no Brasil}

\subsubsection{A Instrução CVM n $\quad$ n 380,23 de dezembro de 2002}

No Brasil, a primeira forma de acesso eletrônico foi o "home broker" implantado pela então Bolsa de Valores de São Paulo, em 1999. O crescimento do uso dessa nova forma de acesso, bem como a necessidade de regulamentação adequada, resultaram, em 2002, na edição da Instrução CVM n 380, que estabelece normas e procedimentos a serem observados nas operações realizadas em bolsas e mercados de balcão organizado por meio da rede mundial de computadores.

As primeiras disposições da Instrução CVM no 380 denotam que a principal preocupação da Autarquia no que tange às operações pela Internet era relacionada à divulgação de informações ao investidor.

Já em seu artigo $3^{\circ}$ a Instrução estabelece a forma como devem constar, das suas páginas na rede mundial de computadores, fazendo uso dos termos "clara, precisa e em linguagem acessível ao público investidor”, as informações consideradas relevantes, as quais são, em seguida enumeradas nos incisos.

Em resumo, a CVM determinou que os intermediários divulguem instruções de uso do sistema de negociação, bem como os procedimentos a serem seguidos pela corretora para a execução das ordens. Determinou, ainda, que fossem dadas informações sobre os valores mobiliários negociados e a política de cobrança de taxas de corretagem e custos adicionais.

As disposições do artigo $4^{\circ}$ visam a esclarecer o investidor acerca do funcionamento do mercado, dando destaque, dentre outros assuntos, aos riscos incorridos pelo investidor, inclusive os riscos operacionais que decorrem do uso da Internet. $\mathrm{O}$ mesmo artigo trata, ainda, das informações acerca da autorregulação que devem necessariamente ser colocadas à disposição do cliente, sobretudo alertando-o sobre a possibilidade de cancelamento de negócios se constatada alguma irregularidade.

Em seu parágrafo único, o artigo $4^{\circ}$ apresenta o texto do aviso que deve destaque nas páginas do intermediário na Internet: "TODA COMUNICAÇÃO ATRAVÉS DA REDE MUNDIAL DE COMPUTADORES ESTÁ SUJEITA A INTERRUPÇÕES OU ATRASOS, PODENDO IMPEDIR OU PREJUDICAR O ENVIO DE ORDENS OU A RECEPÇÃO DE INFORMAÇÕES ATUALIZADAS". 
Outra grande preocupação da Autarquia reside em garantir a disponibilidade do sistema de acesso eletrônico para os investidores. Para tanto a CVM incumbiu às entidades administradoras do mercado organizado a fixação de limites mínimos aceitáveis para os indicadores de capacidade dos sistemas.

Tais indicadores, grosso modo, se baseiam no tempo decorrido entre o envio e a recepção de mensagens entre os envolvidos no processo de negociação, ou seja, cliente, intermediário e entidade administradora do mercado. Os indicadores de capacidade devem ser medidos a cada ordem recebida e devem permanecer arquivados pelo prazo mínimo de um ano.

A exigência de planos de contingência é definida no artigo $6^{\circ}$, visando à preservação do atendimento ao cliente "nos casos de suspensões no atendimento pela rede mundial de computadores, períodos de alta volatilidade no mercado ou picos de demanda".

Os artigos $7^{\circ}$ e $8^{\circ}$ tratam da segurança do sistema, atribuindo ao intermediário a responsabilidade pela sua operacionalidade, mesmo que os sistemas sejam mantidos por terceiros. Adicionalmente, se estabelece que compete ao intermediário garantir a segurança e sigilos de toda informação sobre os clientes, inclusive as informações de negócios realizados e carteira de valores mobiliários. ${ }^{108}$

Os registros de ordens recebidas, executadas ou não, devem ser mantidos pelo prazo de 5 anos, de acordo com o que determina o art. $9^{\circ}$ da Instrução CVM n ${ }^{\circ}$ 380/2002. O mesmo artigo estabelece, no parágrafo único, as comunicações que necessariamente devem ser feitas pelo intermediário ao investidor: (i) do recebimento da ordem no sistema eletrônico do intermediário; (ii) do registro da ordem no sistema eletrônico da entidade administradora; (iii) da execução da ordem; e (iv) se for o caso, do cancelamento da compra ou venda de valores mobiliários, incluindo sua motivação.

A Instrução abre a possibilidade de que os intermediários ofereçam serviços de publicação de mensagens, que podem conter, inclusive análises de emissores ou de valores mobiliários. No entanto, cabe ao intermediário o estabelecimento e comunicação à CVM de "procedimentos internos para coibir a prática de manipulação de preços e divulgação de informações falsas ou prejudicialmente incompletas por meio de seus serviços de publicação de mensagens". Tais disposições encontram-se nos artigos 10 a 12 da Instrução.

\footnotetext{
${ }^{108} \mathrm{O}$ sigilo das operações de instituições financeiras, aliás, já estava previsto na Lei Complementar $\mathrm{n}^{\circ} 105$, de 10 de janeiro de 2001, em cujo artigo primeiro lê-se que: "As instituições financeiras conservarão sigilo em suas operações ativas e passivas e serviços prestados".
} 
Visando à transparência, bem como que o investidor negocie ignorando fatos relevantes publicados que podem afetar as cotações do papel que ele deseja negociar, estabeleceu o artigo 13 que os intermediários devem fazer constar de suas páginas na Internet uma lista ou atalho para consulta a fatos relevantes divulgados nos últimos 5 dias úteis.

No artigo 14 está definida a responsabilidade das entidades administradoras de mercados organizados realizarem auditorias semestrais nos intermediários que oferecem o serviço de acesso eletrônico pela Internet. Tal auditoria, visa a checar a adequação do fornecimento de informações ao cliente e o atendimento aos indicadores de capacidade, e produz relatórios que são encaminhados à CVM.

$\mathrm{O}$ artigo 15 determina que os intermediários disponham de meios alternativos de atendimento aos clientes nos casos de "(i) procedimentos especiais de leilão que ocorram durante o pregão; e operações nos mercados derivativos, se houver." A informação de que trata esse artigo deve ser fornecida ao cliente no ato do seu cadastramento junto ao intermediário.

Por fim, o artigo 20 estabelece que se aplicam às negociações realizadas por intermediários que concedem acesso eletrônico pela Internet, as demais normas da CVM que regulam a atividade de intermediação.

A principal norma da Autarquia quanto à atividade de intermediação é a Instrução CVM n⿳ 387, de 2003, (com alterações introduzidas pelas Instruções CVM nº 395, de 2003, e 419, de 2005) que será foco do próximo tópico.

\subsubsection{A Instrução CVM no 387 , de 28 de abril de 2003}

Tal diploma "estabelece normas e procedimentos a serem observados nas operações realizadas com valores mobiliários, em pregão e em sistemas eletrônicos de negociação e de registro em bolsas de valores e de bolsas de mercadorias e futuros".

Inegável a importância da Instrução CVM no 387 para a regulação da atividade de intermediação no mercado secundário de valores mobiliários no Brasil. No entanto, a nova estrutura do mercado e a introdução de inovações tecnológicas que, como visto, alteram significativamente a atuação do intermediário, já reclamam uma nova postura do regulador, mais sintonizada com a valorização das atividades de controle desempenhadas pelo intermediário. Por essa razão a CVM prepara uma nova Instrução, já 
submetida à Audiência Pública, que deve revogar a Instrução CVM no 387 ainda durante o ano de 2010.

A comparação entre os dois textos é importante para que se possam perceber quão relevantes são as alterações que o novo normativo deve trazer, alterações essas que refletirão na organização forma de atuação dos intermediários no Brasil. Para tanto será utilizada a minuta que foi submetida à audiência pública e, desde já se faz a observação de que seu texto pode sofrer alterações decorrentes das muitas sugestões que certamente recebeu. No entanto, considerando que ele reflete a impressão da Autarquia sobre a atividade de intermediação e a nova configuração do mercado, ainda que alterações venham a ser feitas, sua essência deverá ser preservada.

Uma das principais questões que exsurgem da comparação da Instrução CVM nº 387 com a minuta da Instrução que deve substituí-la é a valorização das atividades de controle impostas aos intermediários.

As atividades de controle, na Instrução muito relacionadas ao cadastro dos clientes, na minuta adquirem tal relevância que passa a ser exigida do intermediário a designação de um diretor responsável pela supervisão dos procedimentos e controles internos que deverão necessariamente ser implantados por todos os intermediários.

A minuta fixa, ainda, a obrigatoriedade de que tais procedimentos $\mathrm{e}$ controles internos, ao lado das regras que o intermediário deve adotar para o cumprimento do disposto no normativo, devem ser escritos e passíveis de verificação, o que cria a chamada trilha de auditoria para a supervisão tanto do regulador, quanto do autorregulador.

Tão importante quanto isso, é a disposição de que será considerado descumprimento da obrigação de estabelecimento de regras, procedimentos e controles internos, não apenas a sua inexistência, mas também a sua não-implementação ou implementação falha ou inadequada, o que se evidenciará, inclusive, pela reiterada ocorrência de falhas.

Essa última disposição cria um critério para avaliar os procedimentos e controles dos intermediários e, sobretudo, cria um mecanismo para evitar que tais procedimentos só existam no papel e valoriza a sua execução.

Assim procedendo, a Autarquia mostra não estar disposta a aceitar que intermediários adquiram vantagens competitivas abrindo mão de procedimentos de controle e sinaliza a importância desses procedimentos para a higidez do mercado. 
Frise-se que o diretor responsável pelos procedimentos e controles internos não substitui o diretor responsável pelo cumprimento das normas estabelecidas pela Instrução, figura já consagrada no artigo $4^{\circ}$ da Instrução CVM no 387 , este é responsável pela implementação de normas, aquele pela sua supervisão. Trata-se, na verdade de função adicional criada em razão da importância que os controles internos estão adquirindo e para dar-lhes efetividade.

Não é por outra razão que dentre as atribuições desse diretor, estará o envio semestral de relatório, aos órgãos de administração do intermediário, contendo as conclusões dos exames que tenha efetuado, as recomendações acerca de eventuais deficiências encontradas e os procedimentos a serem adotados para saná-las. Embora a minuta não estabeleça que esse relatório deva ser encaminhado aos reguladores e autorreguladores, ele certamente será exigido quando das auditorias periódicas feitas nos intermediários por essas instituições.

Cabe destacar ainda, que a minuta, sem prejuízo da responsabilidade do diretor responsável pela implementação da norma e do responsável pela sua supervisão, cria incentivos a que toda a administração do intermediário esteja envolvida no processo ao prever que cabe aos órgãos da administração tanto a aprovação das regras e procedimentos adotados para o cumprimento das normas, quanto a supervisão do seu cumprimento e a efetividade dos procedimentos e controles internos implementados.

Ainda sobre esse assunto, diga-se que a atribuição de responsabilidade a uma pessoa específica tem-se mostrado efetiva para os fins de regulação, mas que o cumprimento de regras e implementação de procedimentos e controles internos devem ser encarados como responsabilidade de toda a administração do intermediário.

No que diz respeito às normas de conduta dos intermediários, a minuta estabelece uma série de obrigações aos intermediários, muitas das quais já presentes na Instrução CVM nº 387.

Duas novidades merecem especial destaque. A primeira diz respeito à atribuição da responsabilidade pela fixação dessas regras de conduta: a Instrução determina que as regras sejam estabelecidas pela bolsa (entidade administradora do mercado), enquanto a minuta dispõe que "cabe à entidade administradora de mercado organizado em que o intermediário estiver autorizado a operar definir o conteúdo mínimo, aprovar e 
fiscalizar as regras internas adotadas por cada intermediário autorizado a operar nos mercados que administre..."109.

Embora sutil a diferença é importantíssima. Pelas normas da Instrução a entidade administradora fixa as regras de conduta que devem ser seguidas por todos os intermediários. Por estranho que pareça, não há na Instrução um dispositivo que obrigue os intermediários a seguirem as regras de conduta, o que impede a sanção em casos de descumprimento, em razão da atipicidade da conduta.

A minuta, por outro lado, determina que seja estabelecido, pelas entidades administradoras, conteúdo mínimo para as normas de conduta, mas atribui expressamente ao intermediário a obrigação de cumpri-las, o que viabiliza a aplicação de sanções em casos de descumprimento.

A segunda novidade diz com a introdução, dentre os deveres de conduta dos intermediários, de princípio relativos ao dever de verificar a adequação da operação ao perfil de risco do cliente e seus objetivos de investimento, antes de realizar a operação. Essa verificação de adequação, conhecida pelo termo "suitability", está prevista na minuta como um princípio, já que também há uma minuta específica sobre o tema, ainda não editada.

A CVM também inovou ao determinar que as ordens dos clientes sejam executadas nas condições mais favoráveis possíveis, com a finalidade de, nas palavras do Edital de Audiência Pública no 04/2009 (p. 05), “... aumentar a proteção aos investidores, conferindo maior efetividade ao dever fiduciário dos intermediários, que devem agir no melhor interesse de seus clientes."

Esse princípio, conhecido internacionalmente como "best execution", adquire especial importância se for permitida a concorrência entre diversos ambientes ou sistemas para a negociação de um mesmo valor mobiliário. Sabe-se que a Instrução CVM

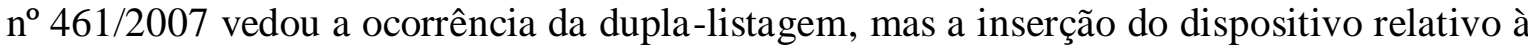
"best execution" no texto da minuta da Instrução que deve substituir à 387, deixa clara a disposição da Autarquia de rever, no futuro, aquele dispositivo.

Quanto aos avanços tecnológicos que têm se acentuado nos últimos anos e que em grande parte explicam a necessidade de aperfeiçoamentos da regulação da intermediação, a CVM reconheceu sua relevância ao disciplinar a transmissão de ordens por meio das conexões automatizadas.

\footnotetext{
${ }^{109}$ Minuta anexa ao Edital de Audiência Pública nº 04/09, artigo 32.
} 
Sem mencionar o termo, a minuta da Instrução, aceita o acesso eletrônico ao mercado e admite que ele precisa de regras específicas, mas incumbe as entidades administradoras de mercado da sua fixação.

Foi contratual a solução encontrada para resolver o problema da competência da autorregulação sobre os investidores que acessem eletronicamente o mercado. A minuta dispõe que dentre as regras que devem ser fixadas pela entidade administradora do mercado, deve constar a submissão (por disposição contratual expressa) do investidor a quem for concedido o direito de acesso eletrônico, ao poder de autorregulação da mencionada entidade, no que concerne à utilização dos sistemas eletrônicos de conexões automatizadas.

Independente da forma de transmissão das ordens dos clientes (a minuta prevê três formas: (i) por escrito; (ii) por telefone e outros sistemas de transmissão de voz; ou (iii) por sistemas de conexões automatizadas), todas elas deverão ser registradas, devendo conter o horário de seu recebimento, a identificação do cliente que as tenha emitido e as condições de execução.

A gravação das ordens transmitidas por telefone, atualmente facultativa, passará a ser obrigatória. Foi mantido o prazo de guarda dos registros por cinco anos, mas foi introduzido um dispositivo que obriga a que o sistema de arquivo dos registros seja protegido contra adulterações, bem como que permita a realização de auditorias e inspeções.

Finalmente, no que diz respeito à autorregulação, a minuta reforça a importância das atividades desempenhadas pelas entidades administradoras do mercado, aumentando sua participação na disciplina das atividades do intermediário, o que se coaduna com a valorização da atividade de autorregulação verificada na Instrução CVM n ${ }^{\circ}$ $461 / 2007$.

Curioso notar que a Instrução CVM no 387 é muitas vezes referida pelos participantes do mercado como "a Instrução de cadastro". Não há duvidas de que a atividade de elaboração dos cadastros e os procedimentos de cadastramento são fundamentais para a consecução de alguns objetivos da minuta em debate (dentre os quais a realização de operações de acordo com o perfil e objetivos do cliente, por exemplo), mas a CVM optou por consolidar num anexo à Instrução CVM no 301, de 1999, o conteúdo mínimo dos cadastros dos clientes junto ao intermediário. 
Disso não decorre que o cadastro tenha sido esquecido na minuta, pelo contrário, todas as regras gerais aplicáveis ao cadastro, bem como a possibilidade de confecção de cadastros simplificados constam da minuta da Instrução que substituirá à Instrução no 387 , de 2003.

\subsubsection{A Instrução CVM no $\quad$ 301, de 16 de abril de 1999}

Como antes ressaltado, o intermediário é um "gatekeeper". Poucas normas exemplificam tão bem essa função quanto a Instrução CVM no 301, de 1999. Decorrente da Lei $n^{\circ}$ 9.613, de 3 de março de 1998, a Instrução CVM no 301 dispõe sobre a identificação, o cadastro, o registro, as operações, a comunicação, os limites e a responsabilidade administrativa de que trata a mencionada lei, em relação aos crimes de "lavagem" ou ocultação de bens, direitos e valores.

A Instrução visa a estabelecer procedimentos que contribuam para a prevenção dos crimes conhecidos como de "lavagem de dinheiro". Para tanto, como anteriormente mencionado, a Instrução explicita as normas conhecidas como "conheça seu cliente", determinando a identificação de todos os clientes dos intermediários por meio da elaboração de cadastro cujo conteúdo mínimo também foi submetido à Audiência Pública ${ }^{110}$ e deve brevemente ser alterado, consolidando todos os requisitos cadastrais em um anexo a seu texto.

A Instrução CVM n ${ }^{\circ}$ 301/1999 estabelece que os intermediários ${ }^{111}$ devem dispensar especial atenção a seguintes operações com valores mobiliários, constantes dos incisos do caput do artigo $6^{\circ}$ :

"I - operações cujos valores se afigurem objetivamente incompatíveis com a ocupação profissional, os rendimentos e/ou a situação patrimonial ou

\footnotetext{
${ }^{110}$ Trata-se da mesma Audiência Pública no 04/09 que também submeteu ao público a minuta da Instrução que deve revogar a Instrução CVM no 387. No caso da Instrução nº 301, não haverá revogação, mas será editada uma Instrução alteradora.

${ }^{111}$ Na realidade o âmbito da Instrução CVM no 301/1999 é maior do que o dos intermediários, conforme se pode verificar em seu artigo $2^{\circ}$ “Art. $2^{\circ}$ - Sujeitam-se às obrigações previstas nesta Instrução as pessoas jurídicas que tenham, em caráter permanente ou eventual, como atividade principal ou acessória, cumulativamente ou não, a custódia, emissão, distribuição, liquidação, negociação, intermediação ou administração de títulos ou valores mobiliários, assim como as bolsas de valores, as entidades do mercado de balcão organizado e as bolsas de mercadorias ou futuros, além das demais pessoas referidas no art. $9^{\circ}$ da Lei $n^{\circ}$ 9.613/98, que se encontrem sob a disciplina e fiscalização exercidas pela CVM, e dos administradores das pessoas jurídicas."
} 
financeira de qualquer das partes envolvidas, tomando-se por base as informações cadastrais respectivas;

II - operações realizadas entre as mesmas partes ou em benefício das mesmas partes, nas quais haja seguidos ganhos ou perdas no que se refere a algum dos envolvidos;

III - operações que evidenciem oscilação significativa em relação ao volume e/ou freqüência de negócios de qualquer das partes envolvidas;

IV - operações cujos desdobramentos contemplem características que possam constituir artifício para burla da identificação dos efetivos envolvidos e/ou beneficiários respectivos;

V - operações cujas características e/ou desdobramentos evidenciem atuação, de forma contumaz, em nome de terceiros;

VI - operações que evidenciem mudança repentina e objetivamente injustificada relativamente às modalidades operacionais usualmente utilizadas pelo(s) envolvido(s);

VII - operações realizadas com finalidade de gerar perda ou ganho para as quais falte, objetivamente, fundamento econômico;

VIII - operações com a participação de pessoas naturais residentes ou entidades constituídas em países e territórios não cooperantes, nos termos das cartas circulares editadas pelo Conselho de Controle de Atividades Financeiras - COAF;

IX - operações liquidadas em espécie, se e quando permitido;

$X$ - transferências privadas, sem motivação aparente, de recursos e de valores mobiliários;

XI - operações cujo grau de complexidade e risco se afigurem incompatíveis com a qualificação técnica do cliente ou de seu representante;

XII - depósitos ou transferências realizadas por terceiros, para a liquidação de operações de cliente, ou para prestação de garantia em operações nos mercados de liquidação futura; e

XIII - pagamentos a terceiros, sob qualquer forma, por conta de liquidação de operações ou resgates de valores depositados em garantia, registrados em nome do cliente." 
Note-se que extenso é o rol de operações a que devem estar atentos os intermediários. Adicionalmente, deverão dispensar especial atenção aos clientes que se enquadrarem nas categorias de: (i) investidores não-residentes, especialmente quando constituídos sob a forma de trusts e sociedades com títulos ao portador; (ii) investidores com grandes fortunas geridas por áreas de instituições financeiras voltadas para clientes com este perfil (“private banking”); e (iii) pessoas politicamente expostas ${ }^{112}$.

Os intermediários devem comunicar à CVM todas as transações, ou propostas de transação que possam constituir-se em sérios indícios de crime de "lavagem" ou ocultação de bens, direitos e valores provenientes dos crimes antecedentes ${ }^{113}$, em que (i) "se verifiquem características excepcionais no que se refere às partes envolvidas, forma de realização ou instrumentos realizados; ou (ii) falte, objetivamente, fundamento econômico ou legal"114.

Note-se, portanto, que os intermediários assumem um verdadeiro papel de fiscais da legalidade das operações realizadas por seus clientes, submetendo-se, em caso de descumprimento, a sanções administrativas fixadas no artigo 12 da Lei $n^{\circ}$ 9.613/98, quais sejam: (i) advertência; (ii) multa pecuniária; (iii) inabilitação temporária; e (iv) cassação da autorização para funcionamento.

\footnotetext{
${ }^{112}$ Pessoas Politicamente Expostas são aquelas que desempenham ou tenham desempenhado, nos últimos 5 (cinco) anos, cargos, empregos ou funções públicas relevantes, no Brasil ou em outros países, territórios e dependências estrangeiros, assim como seus representantes, familiares e outras pessoas de seu relacionamento próximo. A definição de Pessoa Politicamente Exposta (conhecida pela sigla PEP) consta do artigo $3^{\circ}$-B, inciso I, da Instrução CVM nº 301/1999.

${ }^{113}$ São crimes antecedentes os definidos no artigo $1^{\text {o }}$ da Lei 9.613 , de 1998 , quais sejam (i) o tráfico ilícito de substâncias entorpecentes ou drogas afins; (ii) o de terrorismo e seu financiamento; (iii) o contrabando ou tráfico de armas, munições ou material destinado à sua produção;(iv) a extorsão mediante seqüestro; (v) os crimes contra a Administração Pública, inclusive a exigência, para si ou para outrem, direta ou indiretamente, de qualquer vantagem, como condição ou preço para a prática ou omissão de atos administrativos; (vi) os crimes contra o sistema financeiro nacional; (vii) os crimes praticados por organização criminosa; (viii) os crimes praticados por particular contra a administração pública estrangeira.
}

${ }^{114}$ Art. $7^{\circ}$, incisos I e II, da Instrução CVM n ${ }^{\circ}$ 301/1999. 


\section{CONCluSÃo}

O desenvolvimento da tecnologia, sem dúvida, alterou o mercado de valores mobiliários, seja pela introdução de novos produtos cada vez mais sofisticados, seja porque modificou a forma de negociação no mercado.

Em poucos anos os sistemas eletrônicos de negociação ocuparam o espaço antes destinado aos pregões viva-voz, dos quais nem os mais saudosistas parecem sentir falta.

Os ambientes de negociação altamente informatizados geraram condições para que o acesso do investidor ao mercado seguisse o mesmo caminho, de forma que, atualmente, a maior parte dos negócios executados nas maiores bolsas do mundo, provém de investidores com alguma forma de acesso eletrônico.

A existência de mais de um tipo de acesso eletrônico ao mercado dá uma boa pista de qual deve ser o papel do intermediário no mercado de valores mobiliários.

Nos acessos eletrônicos por roteamento de ordens o intermediário continua desempenhando a mesma função que sempre desempenhou. O que mudou foi a forma de se fazer isso.

Nesse tipo de acesso as ordens passam pelo intermediário antes de seguirem para os sistemas de negociação. Embora a velocidade tenha mudado, os controles devem permitir que o intermediário impeça a execução de ordens que se mostrem incompatíveis com a capacidade de liquidação do investidor, por exemplo, o que se faz pelo aperfeiçoamento dos procedimentos de controle, tais como a instalação de filtros prénegociação.

O acesso patrocinado, em que as ordens não passam pelo intermediário antes de serem executadas, impõe maiores dificuldades aos intermediários. Aí provavelmente estarão os "high frequency traders" e sua ânsia por reduzir, ao mínimo possível, a latência. Nesse caso, o controle será pós-negociação e sua efetividade dependerá da eficiência da entidade administradora do mercado em proporcionar informações sobre a negociação em tempo real. De qualquer forma, a experiência mostra que nesse caso, o conhecimento que o intermediário tenha do cliente é ainda mais importante. 
Deve-se considerar também que o investidor que busca acesso por meio do roteamento não é necessariamente o mesmo que pretende ter acesso patrocinado. Ainda que o fosse, está na discricionariedade do intermediário conceder ou não acesso aos clientes. Não se deve esquecer que o intermediário assume a responsabilidade pelas ordens do seu cliente, independentemente do tipo de acesso que ele tenha.

Por essa razão se diz que a atividade do intermediário é, cada vez mais, de gestão de riscos. Essa gestão começa no primeiro contato com o cliente e se perpetua por todo o tempo em que se mantenham as relações comerciais. Quanto mais informações o intermediário tiver a respeito do cliente, melhores serão os controles que poderá implantar.

Para um intermediário a qualidade dos controles pode ser uma questão de sobrevivência. O controle de riscos não é um fim em si mesmo, nem apenas uma forma de atender à regulação, deve sim ser encarado como uma maneira de garantir a solidez do intermediário, uma boa gestão de riscos agrega valor ao negócio.

Já para o regulador, um bom controle de riscos por cada intermediário individualmente, reduz o risco total do mercado e vai ao encontro dos objetivos de todo o regulador: crescimento do mercado com equidade e transparência.

Voltando os olhos para dentro, no Brasil a regulação atual não permite o acesso direto do investidor ao mercado de bolsa. Tal acesso só se faz por meio de um intermediário, ainda que eletronicamente.

No segmento de ações, o único acesso eletrônico permitido até o momento é o feito por roteamento de ordens. Há demanda da Bolsa para que se possa oferecer o acesso patrocinado e "co-location", mas ainda não houve aprovação da Comissão de Valores Mobiliários para tal. No segmento de derivativos, como antes apontado, a BM\&FBOVESPA já oferece todas as formas de acesso eletrônico, evidentemente todas intermediadas.

Até o momento, não se verificou que as formas de acesso eletrônico tenham gerado problemas no mercado brasileiro, o que pode ser atribuído, pelo menos em parte tanto à regulação quanto à autorregulação.

Não se trata de afirmação ufanista. Uma análise superficial dos Princípios propostos pela IOCV/IOSCO e da disciplina adotada no Brasil já permite concluir que a regulação e a autorregulação do Brasil já adotam as práticas consideradas como as mais adequadas no contexto do acesso eletrônico ao mercado. 
Um possível Princípio da OICV/IOSCO sobre o acesso eletrônico diz respeito à necessidade de contrato que vincule juridicamente o intermediário e o cliente, prática já implantada no Brasil pela autorregulação.

Outro possível Princípio recomenda que o intermediário seja obrigado a identificar seu cliente com acesso eletrônico mediante requisição do regulador. No Brasil todo o comitente final de operações é identificado pela entidade administradora do mercado, a qual dá pleno acesso dessas informações ao regulador.

Ainda outro Princípio recomenda que as entidades administradoras do mercado devem dar às pessoas autorizadas a operar, acesso a informações pré e pós negociação (em tempo-real) necessárias para a implementação de controles de risco e monitoramento apropriados. Tais informações já estão disponíveis no mercado brasileiro e não só apenas para os investidores com acesso eletrônico.

Conclui-se, portanto, que não há problemas regulatórios relacionados ao acesso eletrônico no Brasil. As normas que regem esse acesso estão em conformidade com as melhores práticas regulatórias.

Há, no entanto, uma restrição ao acesso não intermediado no mercado de ações que não se observa em muitos outros países. Penso que, ainda que essa restrição não existisse, esse tipo de acesso seria muito pequeno ou até inexistente, já que dependeria da Bolsa a sua concessão.

Quanto à figura do intermediário, a mencionada restrição faz com que ele continue sendo imprescindível no mercado secundário de ações. Igualmente, penso que, mesmo que a norma fosse diversa, o intermediário continuaria a ser parte importante do processo de negociação. Ele não é apenas um "gatekeeper" que impede a ocorrência de irregularidades, mas ele também contribui com sua atividade para dar credibilidade ao mercado.

Para finalizar, recorro às palavras de Franklin Allen e Anthony Santomero $^{115}$ :

"Financial markets and financial intermediaries then have a symbiotic relationship. Each is necessary to the other. Without intermediaries, the informational barriers to participation would prevent investors from reaping the benefits of new markets, and the markets themselves might not survive."

${ }^{115}$ In ALLEN e SANTOMERO, ob. cit., p. 289. 


\section{BIBLIOGRAFIA}

ABRÃO, Nelson. Direito Bancário. $9^{a}$ Edição revista, ampliada e atualizada por Carlos Henrique Abrão. São Paulo: Saraiva, 2005.

AITKEN, Michael J., HARRIS, Frederick H. deB., JI, Shan. Trade Based Manipulation and Market Efficiency: A Cross-Market Comparison. 2009.

AKERLOF, G. The Market for Lemons: qualitative uncertainty and the market mechanism. Quarterly Journal of Economics, vol. 84, n. 3, 1970.

ALLEN, F. e GALE, D. (1995). "A welfare comparison of intermediaries and financial markets in Germany and the US," European Economic Review, 39 (2), 179-209.

. "Financial Markets, Intermediaries, and Intertemporal Smoothing," Journal of Political Economy, 105 (3), 523-546.

ALLEN, F. e SANTOMERO, A. (1997). "The theory of financial intermediation," Journal of Banking and Finance, 21 (11-12), 1461-1485. 271-294.

"What do financial intermediaries do?" Journal of Banking and Finance, 25 (2),

ALLEN, Helen, HAWKINS, John, SATO, Setsuya. Electronic Trading and its implication for financial systems. BIS Papers $\mathrm{n}^{\circ}$ 7: Electronic finance: a new perspective and challenges, BIS - Bank for International Settlements, 2001

ANDREZO, Andrea Fernandes. LIMA, Iran Siqueira. Mercado Financeiro: Aspectos Históricos e Conceituais. São Paulo: Pioneira, 1999.

ARSHADI, Nasser. KARELS, Gordon V. Modern Financial Intermediaries and Markets. Upper Saddle River, NJ: Prentice-Hall, c1997.

ASCARELLI, Tullio. Problemas das sociedades anônimas e direito comparado. Campinas: Bookseller, 2001.

BARRETO FILHO, Oscar. Regime Jurídico das Sociedades de Investimento, Max Limonad, 1956.

BATALHA, W.S.C. Sociedades Anônimas e Mercado de Capitais. Rio de Janeiro: Forense, 1973.

BLACK, Bernard S. Strengthening Brazil's Securities Markets. Stanford Law School, 2000. Disponível em: < http://ssrn.com/abstract=247673>. Acesso em: 12.dez. 2009.

. The Legal and Institutional Preconditions for Strong Securities Markets. UCLA

Law Review, Vol. 48, pp. 781-855, 2001. Disponível em: <http://ssrn.com/abstract=182169>. Acesso em: 17.dez.2008. 
BERGER, A.; DEYOUNG, R.; GENAY, H. e UDELL, G. (1999). "Globalization of Financial Institutions: Evidence from Cross-Border Banking Performance," Federal Reserve Bank of Chicago, WP 99-25.

BERNSTEIN, Peter. A História do Mercado de Capitais - O Impacto da Ciência e da Tecnologia nos Investimentos. Trad. port. Afonso Celso da Cunha Serra. Rio de Janeiro: Elsevier, 2008.

BIS - Bank for International Settlements. The Implications of Electronic Trading in Financial Markets, reported by a working group established by the Committee on the Global Financial System of the Central Banks of the Group of Ten Countries. BIS .2001

CAENEGEM, R. C. Van. Uma Introdução Histórica ao Direito Privado, $2^{\mathrm{a}}$ ed., trad. port. Carlos Eduardo Lima Machado. São Paulo: Martins Fontes, 2000.

CARVALHO DE MENDONÇA, José Xavier. Tratado de direito comercial brasileiro. Campinas: Bookseller, 2001.

CECCHETTI, S. (1999). "The Future of Financial Intermediation and Regulation: An Overview," Federal Reserve Bank of New York, Current Issues in Economics and Finance, 5 (8).

COFFEE, John C. Gatekeepers: The Professions and Corporate Governance. Oxford: Oxforf University Press, 2006.

Privatization and corporate governance: the lessons from securities market failure. Journal of Corporation Law, n. 25, 1999. 2003.

Securities regulation: cases and materials. 9th ed. New York: Foundation Press,

Law and the Market: The Impact of Enforcement. Columbia Law and Economics Working Paper, $\mathrm{n}^{\mathrm{o}}$ 304, 2007. Disponível em: <http://ssrn.com/abstract=967482>. Acesso em 17.dez. 2008.

COMPARATO, Fábio Konder. Natureza Jurídica das Bolsas de Valores e Delimitação do seu Objeto, in Revista de Direito Mercantil, Industrial, Econômico e Financeiro, vol. 60, out/dez 1985, pp. 45-53.

COX, James D.; THOMAS, Randall S. SEC Enforcement Actions for Financial Fraud and Private Litigation: An Empirical Inquiry. Valderbilt Law and Economics Research Paper, no 03-08, 2003. Disponível em: <http://www.ssrn.com/asbstract=429140>. Acesso em: 18 nov. 2008.

Public and Private Enforcement of the Securities Laws: Have Things Changed Since Enron?. Notre Dame Law Review, vol. 80, 2004. Disponível em: <http://ssrn.com/abstract=655201>. Acesso em: 28.dez.2008. 
; HILLMAN, Robert W.; LANGEVOORT, Donald C. Securities Regulation: Cases and Materials. New York: Aspen, 2004.

DE LUCCA, Newton. As Bolsas de Valores e os Valores Mobiliários, in Revista do Tribunal Federal da $3^{\text {a }}$ Região, no 35, jul/set 1998, pp. 19-38.

DE LUCCA, Newton. SIMÃO FILHO, Adalberto (coord.). Direito \& Internet - Aspectos Jurídicos Relevantes. $2^{\text {a }}$ Edição. São Paulo: Quartier Latin, 2005.

Direito \& Internet - Aspectos Jurídicos Relevantes. Volume II. São Paulo: Quartier Latin, 2008.

DIAMOND, D. "Financial Intermediation as Delegated Monitoring: a Simple Example," Federal Reserve Bank of Richmond Economic Quarterly, 82 (3), 51-66.

DUBEUX, Julio Ramalho. A Comissão de Valores Mobiliários e os principais instrumentos regulatórios do mercado de capitais brasileiro. Dissertação de Mestrado Pontifícia Universidade Católica do Rio de Janeiro, Rio de Janeiro, 2005.

EIZIRIK, Nelson. O papel do Estado na regulação do mercado de capitais. Rio de Janeiro: IBMEC, 1977. 145 p. (Série Estudos Especiais n. ${ }^{\circ}$ 3).

. Regulação e auto-regulação do mercado de valores mobiliários. Revista de Direito Mercantil, Industrial, Econômico e Financeiro, São Paulo, nova série, v.21, nº 45, p. 48 59, jan./mar. de 1982.

EIZIRIK, Nelson, GALL, Ariádna. PARENTE, Flávia. HENRIQUES, Marcus de Freitas. Mercado de Capitais - Regime Jurídico. $2^{\mathrm{a}}$ Edição. Rio de Janeiro: Renovar, 2008.

FABOZZI, Frank J. e MODIGLIANI, Franco. Capital Markets - Institutions and Instruments. Prentice Hall, 2009

FERREIRA, Alcides. “A Força dos Pregões”. São Paulo: BM\&F, 2007.

FRIEDMAN, Felice B. e GROSE, Claire. "Promoting Access to Primary Equity Markets A Legal and Regulatory Approach". World Bank Policy Research Working Paper 3892. April 2006.

GALBRAITH, John Kenneth. A short history of financial euphoria. $2^{\mathrm{a}}$ ed. New York: 1993.

GUEDES FILHO, Ernesto Moreira et alli "O Mercado de Capitais: sua importância para o desenvolvimento econômico e os entraves com que se defronta no Brasil". Estudos para o Desenvolvimento do Mercado de Capitais. São Paulo: BOVESPA. 2000.

GOETZMANN, William N. e ROUWENHORST, Geert. The origins of value: the financial innovations that created modern capital markets. New York: Oxford University Press, 2005. 
GROSSE, Robert. The Future of Global Financial Services - Global Dimension in Business, Blackwell, 2004.

HALL, Robert E. e TAYLOR, John B. Macroeconomia - Teoria, Desempenho e Política. Trad. port. José Ricardo Brandão Azevedo. Rio de Janeiro: Campus, 1989

HARRIS, Larry. Trading and Exchanges: Market Microstructure for Practitioners. New York: Oxford University Press, 2003.

IOSCO - Policies on Direct Electronic Access - Consultation Report"- OICV-IOSCO Technical Committee, 2009.

JAIN, Pankaj K. “Financial Market Design and Equity Premium: Electronic versus Floor Trading”, Working Paper, 2006.

LA PORTA, Rafael, LOPEZ-DE-SILANEZ, Florêncio, SHLEIFER, Andrei. Investor protection and corporate governance. Journal of Financial Economics, v.3, 2000.

LEVINE, Ross. "Stock Markets, Growth, and Tax Policy". Journal of Finance, September 1991, 46 (4).

LEVINE, Ross e ZERVOS, Sara. "Stock Markets, Banks, and Economic Growth", The American Economic Review, Vol. 88, n 3.1998

LÉVY, Pierre. O que é o Virtual? Tradução de Paulo Neves. São Paulo: Editora 34, 1996. . Cibercultura. Tradução de Carlos Irineu da Costa. São Paulo: Editora 34, 1999. . As Tecnologias da Inteligência: O Futuro do Pensamento na Era da Informática. Tradução de Carlos Irineu da Costa. Rio de Janeiro: Editora 34, 1993.

LEWIS, M. Financial Intermediaries (The international library of critical writings in economics, vol. 43), Edward Elgar Pub, 1995.

LOSS, Louis. Securities Regulation. Boston-Toronto: Little Brown and Company, 1961. 2001. ; SELIGMAN, Joel. Fundamentals of Securities Regulation. New York: Aspen,

MADHAVAN, Ananth. "Market Microstructure: a Survey", 2000,

Disponível em http://ssrn.com/abstract=218180 or doi:10.2139/ssrn.218180, último acesso em 09/01/2009

MARCHI, Eduardo C. Silveira. Guia de Metodologia Jurídica (Teses, Monografias e Artigos). Lecce: Edizioni del Grifo, 2002.

MOURA, Alex Soares de. Roteamento: O que é importante saber. Rede Nacional de Ensino e Pesquisa. 
MURPHY, Antoin E. John Law: innovating theorist and policymaker in The origins of value: the financial innovations that created modern capital markets. Oxford: Oxford Press, 2005 , p. 225/248.

NORONHA, Ilene Patrícia de. "Aspectos Jurídicos da Negociação de Valores Mobiliários via Internet”, in Direito e Internet - Aspectos Jurídicos Relevantes, São Paulo: Quartier Latin, $2^{\text {a }}$ Ed., 2005, pp. 209-236

OLIVEIRA, Marcos Cavalcante. Moeda, Juros e Instituições Financeiras: Regime Jurídico. Rio de Janeiro: Forense, 2006.

POSNER, Richard A. Economic Analysis of Law. 3 ed. Boston e Toronto: Little, Brown and Company, 1986.

PROENÇA, José Marcelo Martins. Insider Trading - Regime jurídico do uso de informações privilegiadas no mercado de capitais, São Paulo: Quartier Latin, 2005

ROUSSEAU, P. e WACHTEL, P. (1998). "Financial Intermediation and Economic Performance: Historical Evidence from Five Industrialized Countries," Journal of Money, Credit, and Banking, 30 (4), 657-678.

SALLES, Marcos Paulo de Almeida. Mercado de Valores Mobiliários e Comissão de Valores Mobiliários. São Paulo: Resenha Universitária, 1980.

SALOMÃO FILHO, Calixto. Regulação da atividade econômica: princípios $e$ fundamentos jurídicos. São Paulo: Malheiros, 2001.

SALOMÃO NETO, Eduardo. Direito Bancário. São Paulo: Atlas, 2005.

SCHWARTZ, Robert. A. BYRNE, John Aidan. COLANINNO, Antoinette. Electronic vs. Floor Bases Trading. New York: Springer, 2006.

SCHUMPETER, Joseph A. "A Teoria do Desenvolvimento Econômico. Uma Investigação sobre Lucros, Capital, Crédito, Juro e o Ciclo Econômico", (1934) trad. port. Maria Sílvia Possas. Os Economistas. São Paulo: Ed. Nova Cultural, 1997.

SKEETE, Herbie. The Future of the Financial Exchanges - Insights and Analysis from the Mondo Visione Exchange Forum. Elsevier, 2009.

SZTAJN, Rachel. Regulação e mercado de valores mobiliários. Revista de Direito Mercantil, Industrial, Econômico e Financeiro, São Paulo, v.43, $\mathrm{n}^{\circ}$ 135, p. 136-147, jul./set. de 2004.

TRAKMAN, Leon E. The law merchant: the evolution of commercial law. Littleton: Fred B. Rothman, 1983.

VERÇOSA, Haroldo Malheiros Duclerc. Bancos Centrais no Direito Comparado - O Sistema Financeiro Nacional e o Banco Central do Brasil $(O$ regime vigente e as propostas de reformulação). São Paulo: Malheiros, 2005. 
WAISBERG, Ivo. FONTES, Marcos Rolim Fernandes (coord.). Contratos Bancários. São Paulo: Quartier Latin, 2006.

WILLIAMSON, S. Recent Developments in Modeling Financial Intermediation. Federal Reserve Bank of Minneapolis Quarterly Review, Verão 1987, 19-29.

WHITE, Lawrence J. White. Technologial Change, Financial Innovation, and Financial Regulation in the U.S.: The Challenges for Public Policy. in Performance of Financial Institutions - Efficiency, Innovation, Regulation, Cambridge University Press, 2000

YAZBEK, Otavio. Regulação do Mercado Financeiro e de Capitais. Rio de Janeiro: Elsevier, 2007. 